\title{
Puma and to a lesser extent Noxa are suppressors of Myc-induced lymphomagenesis
}

\author{
EM Michalak ${ }^{1,2,3}$, ES Jansen ${ }^{1}$, L Happo ${ }^{1,2}$, MS Cragg $^{1,4}$, L Tai $^{1}$, GK Smyth ${ }^{1}$, A Strasser ${ }^{\star, 1,5}$, JM Adams $^{1,5}$ and CL Scott ${ }^{1,5}$
}

Evasion of apoptosis contributes importantly to c-Myc-induced tumorigenesis. The BH3-only Bcl-2 family members Puma and Noxa are critical pro-apoptotic transcriptional targets of p53, a major mediator of Myc-induced apoptosis and suppressor of Myc-induced tumorigenesis. Hence, we have explored the impact of their individual or combined loss on myc-driven lymphomagenesis. Notably, Puma deficiency both increased B-lineage cells and accelerated the development of B lymphoma, accompanied by leukaemia, but not of pre-B lymphoma. Noxa deficiency alone also increased B-lineage cells but did not accelerate lymphomagenesis. However, its deficiency combined with loss of one puma allele produced more rapid onset of both pre-B and B lymphomas than did loss of a single puma allele alone. Nevertheless, the acceleration evoked by loss of both genes was not as marked as that caused by $\mathrm{p} 53$ heterozygosity. These results show that Puma imposes a significant, and Noxa a minor barrier to c-Myc-driven lymphomagenesis. They also indicate that additional BH3-only proteins probably also drive Myc-induced apoptosis and that non-apoptotic functions of p53 may contribute substantially to its tumour suppressor role.

Cell Death and Differentiation (2009) 16, 684-696; doi:10.1038/cdd.2008.195; published online 16 January 2009

The ability of p53 to induce apoptosis in cells subjected to genotoxic stress or deregulated activation of oncogenes, (e.g., c-myc), is a vital component of its tumour suppressor function. $^{1,2}$ p53 triggers apoptosis through the 'Bcl-2regulated' pathway, as the response can be inhibited by overexpression of $\mathrm{Bcl}-2$ or its pro-survival homologues. ${ }^{3-5}$ The Bcl-2 protein family, which regulates developmentally programmed cell death and cytotoxic stress-induced apoptosis, ${ }^{6-8}$ contains three structurally and functionally distinct subgroups: Bcl-2-like pro-survival proteins, which share up to four $\mathrm{Bcl}-2$ homology $(\mathrm{BH})$ regions; pro-apoptotic Bax/Bak-like proteins, which contain the $\mathrm{BH} 1, \mathrm{BH} 2$ and $\mathrm{BH} 3$ regions; and the pro-apoptotic $\mathrm{BH}$-only proteins, which share only the $\mathrm{BH} 3$ domain. The $\mathrm{BH} 3$-only proteins initiate apoptosis signalling, whereas Bax/Bak-like proteins act downstream by disrupting the mitochondrial outer membrane.

Experiments with genetically modified mice have shown that just as pro-survival Bcl-2 family members can be oncogenic, ${ }^{9}$ certain pro-apoptotic BH3-only proteins (e.g., Bim, Puma) can function as tumour suppressors. ${ }^{10,11}$ Moreover, links between deficiencies in BH3-only proteins - in particular Bim - and human cancer are accumulating. ${ }^{12-14}$

Two BH3-only genes, noxa and puma, are direct transcriptional targets of $\mathrm{p} 53,{ }^{15-17}$ although they can also be induced by p53-independent mechanisms. ${ }^{15,18}$ Studies with genetargeted mice have shown that Puma plays a major role in p53-mediated apoptosis of many cell types, including B and T lymphocytes, as well as in some p53-independent apoptotic pathways ${ }^{19-21}$ and that Noxa participates in the DNA damage response of fibroblasts and keratinocytes. ${ }^{19,22,23}$ Recently, we showed that the combined absence of Noxa and Puma protected mouse embryo fibroblasts from etoposide-induced apoptosis to a greater extent than loss of either gene alone; remarkably, following whole body $\gamma$-irradiation, their concomitant loss protected thymocytes as potently as p53 loss. ${ }^{24}$

As the pro-apoptotic activity of p53 is considered to be critical for its tumour suppressor function ${ }^{1,2}$ and Puma and Noxa appear to be the critical pro-apoptotic effectors induced by p53, animals lacking Noxa or Puma might be expected to be abnormally tumour prone. Surprisingly, however, mice lacking either of these apoptotic triggers, or even both, are not tumour prone. ${ }^{19,20,24}$ Nevertheless, their loss might contribute to tumorigenesis in the context of an oncogenic lesion that activates the p53 pathway.

In $\mathrm{E} \mu-m y c$ transgenic mice, a model of B-lymphoma development, ${ }^{25}$ the high $\mathrm{c}-\mathrm{Myc}$ expression throughout B-cell development provokes an expansion of cycling pre-B cells due to increased proliferation and reduced differentiation from the pre-B to the mature B-cell stage, ${ }^{26}$ which is to a certain extent counter-balanced by increased apoptosis. ${ }^{27}$ Although $\mathrm{E} \mu$-myc mice all eventually develop disseminated pre-B and/or B-cell lymphomas, usually with associated leukaemia, somatic mutations to activate additional oncogenes or inactivate tumour suppressors are required. ${ }^{25,28}$ Transformation by Myc is greatly limited by its tendency to induce apoptosis under stress conditions, such as limiting growth factors. ${ }^{27,29,30}$ Myc triggers apoptosis, in part, by activating the tumour suppressor p19Arf, which upregulates $\mathrm{p} 53$ by

\footnotetext{
${ }^{1}$ The Walter and Eliza Hall Institute of Medical Research, Melbourne, Australia and ${ }^{2}$ Department of Medical Biology, The University of Melbourne, Melbourne, Australia ${ }^{*}$ Corresponding author: A Strasser, The Walter and Eliza Hall Institute of Medical Research, Molecular Genetics of Cancer Division, 1 G Royal Parade, Parkville, Victoria 3050, Australia. Tel: 0061393452624 or 2493; Fax: 006139347 0852; E-mail: strasser@ wehi.edu.au

${ }^{3}$ Current address: Department of Molecular Biology, The Netherlands Cancer Institute, Amsterdam, The Netherlands

${ }^{4}$ Current address: Cancer Sciences Division, Southampton University, Southampton, UK

${ }^{5}$ These authors share senior authorship

Keywords: apoptosis; p53; Puma; Noxa; tumour suppressor

Abbreviations: $\mathrm{BH}, \mathrm{BCl}-2$-homology; DKO, double knockout; DP, double positive

Received 03.6.08; revised 04.12.08; accepted 05.12.08; Edited by M Oren; published online 16.1.09
} 
a
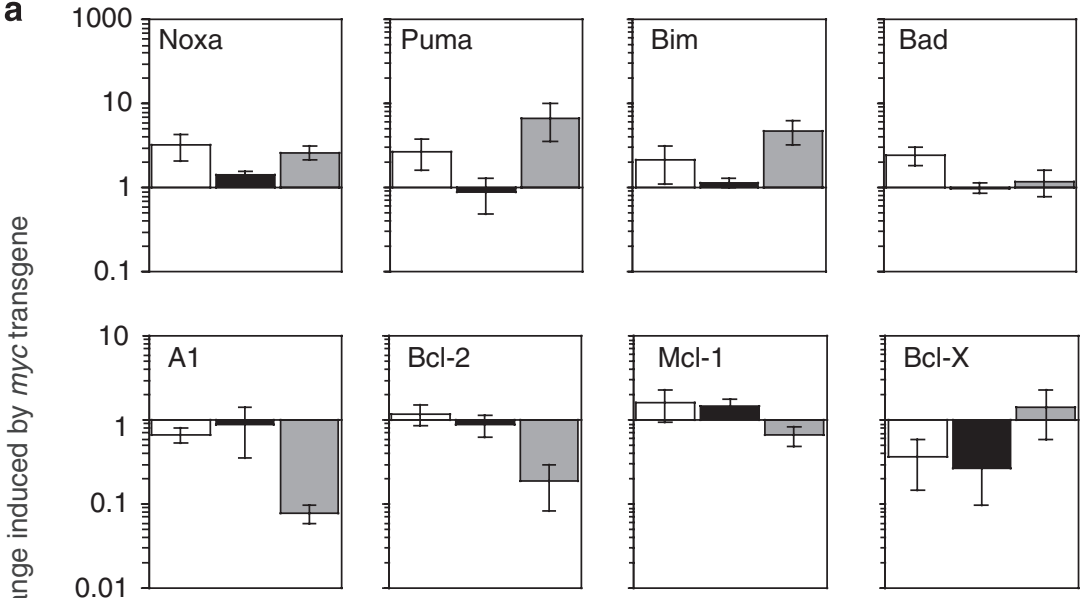

10000
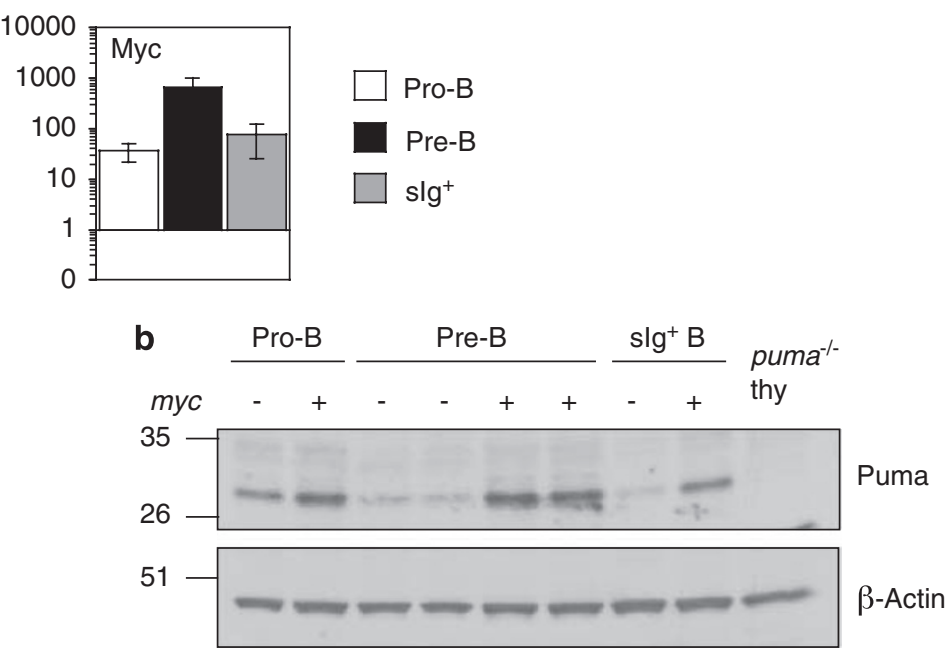

Figure 1 Puma and Noxa expression is increased in B cells from $\mathrm{E} \mu$-myc mice. (a) Differences in the levels of RNA for Bcl-2 family members and Myc between cells from $\mathrm{E} \mu$-myc and non-transgenic mice. Pro-B, pre-B and B-cell subsets were FACS purified from healthy 5- to 6-week-old E $\mu$-myc or non-transgenic syngeneic (C57BL/6) mice. SYBR green real-time PCR analysis was performed on cDNA. Relative RNA expression levels were calculated by normalising to the signal for $\beta$-actin in each sample and then dividing the transgenic by the non-transgenic value. Mean expression is shown \pm S.E.M. of cells from 3-4 individual mice of each genotype from at least three separate experiments. (b) Western blot analysis of Puma and $\beta$-actin (loading control) on protein isolated from the cell populations described in A. Puma-deficient thymocytes were included as a control for antibody specificity. Protein size standards in $\mathrm{kDa}$ are indicated on the left

suppressing Mdm2 activity. ${ }^{31,32}$ Accordingly, E $\mu$-myc lymphomas often contain mutations in the p19Arf/Mdm2/p53 pathway. ${ }^{33}$

To assess the tumour suppressor potential of Puma and Noxa, we have evaluated the impact of their individual or combined loss on lymphoma development in $\mathrm{E} \mu$-myc mice.

\section{Results}

Myc upregulates expression of Puma and Noxa. Myc indirectly upregulates $\mathrm{p} 53,{ }^{31}$ which would be expected to stimulate the transcription of puma and noxa. To investigate the impact of constitutive c-Myc expression on puma and noxa expression in B-lineage cells, we compared the levels of their mRNAs, and those of several other $\mathrm{Bcl}-2$ family members, by qRT-PCR in pro-B, pre-B and $\mathrm{slg}^{+} \mathrm{B}$ cells sorted from the bone marrow of healthy (pre-malignant)
$\mathrm{E} \mu-m y c$ and non-transgenic mice (Figure 1a). As expected, all three $\mathrm{B}$-cell subsets from $\mathrm{E} \mu-m y c$ mice had c-myc levels at least 20 -fold above those from non-transgenic littermates. The levels of noxa mRNA were $\sim 3$-fold higher in pro-B cells from $\mathrm{E}_{\mu}$-myc than non-transgenic mice and $\sim 2.5$-fold higher in the $\mathrm{slg}^{+}$B-cell subset but only marginally higher in the pre-B cells. Similarly, the constitutive Myc expression increased puma mRNA levels $\sim 2.5$-fold in pro-B and $\sim 7$ fold in slg ${ }^{+}$B cells but had no impact in pre-B cells. In accord with a previous study, ${ }^{10}$ bim was also elevated in the $\mathrm{E} \mu$-myc pro-B and $\mathrm{slg}^{+} \mathrm{B}$ cells, whereas bad levels rose only in the pro-B cells. In accordance with other studies, ${ }^{10,34,35}$ Myc overexpression also elicited stage-specific alterations in the levels of the mRNAs for pro-survival Bcl-2 family members (Figure 1a): it did not change the levels of $a 1$ and $b c /-2$ in pre$\mathrm{B}$ cells, but decreased both in $\mathrm{slg}^{+} \mathrm{B}$ cells, whereas $\mathrm{bcl}-\mathrm{x}$ levels were decreased in $\mathrm{E} \mu-m y c$ pro-B and pre-B cells but not in slg $^{+} \mathrm{B}$ cells. 

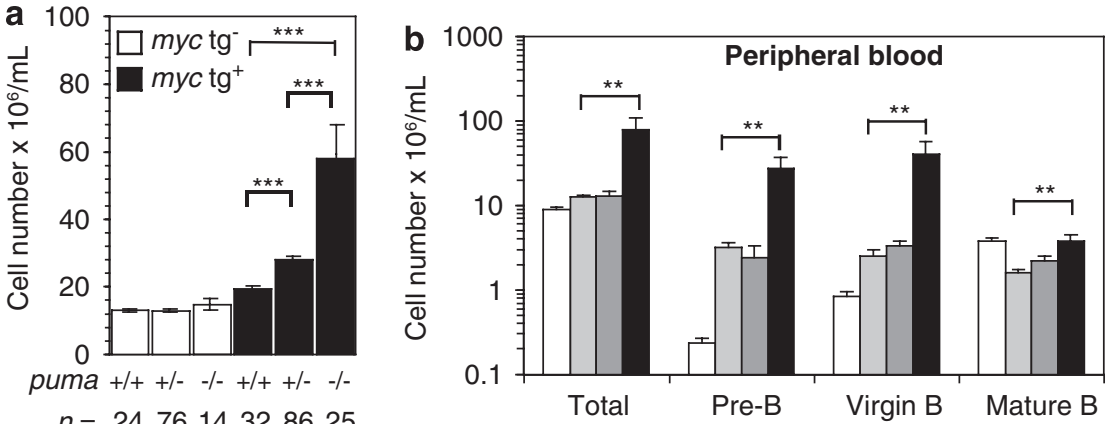

$n=247614328625$

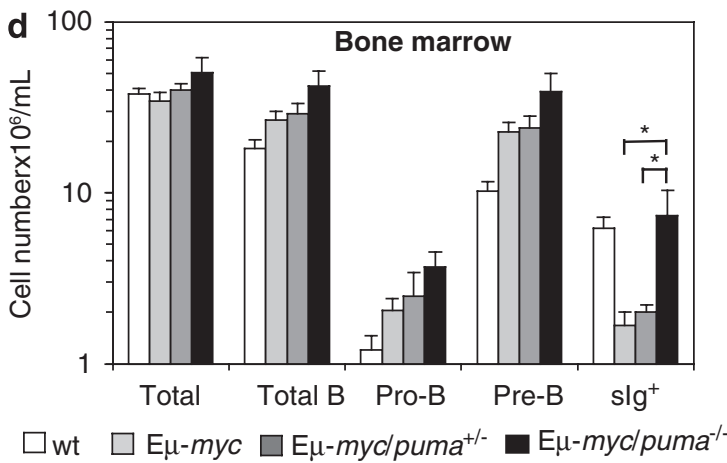

Figure 2 In pre-neoplastic E $\mu$-myc mice, loss of Puma increases leukocytes and B-lymphoid cells. (a) White blood cell counts (means \pm S.E.M.) from pre-neoplastic 4-week-old mice of the indicated $\mathrm{E} \mu$-myc and puma genotypes. Differences between transgenic genotypes were significant as indicated. (b) Blood cellularity and subset composition in pre-neoplastic 5- to 6-week-old mice of the indicated genotypes. All differences between non-transgenic and $\mathrm{E} \mu$-myc mice were significant for all puma genotypes $(P<0.05)$ except for mature B cells from non-transgenic versus $\mathrm{E} \mu$-myc/puma ${ }^{-1-}$ mice. For comparisons of $\mathrm{E} \mu$-myc transgenic mice of the different puma genotypes, statistically significant differences in addition to those indicated, included all subset comparisons between $\mathrm{E}_{\mu-\mathrm{myc} / p u m a}{ }^{+/-}$and $\mathrm{E} \mu-\mathrm{myc} /$ puma ${ }^{-1-}$ mice. (c) Spleen weights (means \pm S.E.M.) of pre-neoplastic 5- to 6-week-old mice. Differences between non-transgenic and $\mathrm{E} \mu$-myc mice were significant for all puma genotypes $(P<0.03)$, and for those indicated. (d) Bone marrow cellularity (both femora) and subset composition in pre-neoplastic 5- to 6-week-old mice of the indicated genotypes. Differences between non-transgenic and $\mathrm{E} \mu$-myc mice were significant $(P<0.05)$ for all puma genotypes for total $\mathrm{B}$ and pre-B cell comparisons and for reduction in mature $\mathrm{B}$ cells for wt versus $\mathrm{E} \mu$-myc and wt versus $\mathrm{E} \mu$-myc/puma ${ }^{-1-}$ mice. For comparisons of the $\mathrm{E} \mu$-myc transgenic mice of the different puma genotypes, all statistically significant differences are indicated. Values represent means \pm S.E.M. from 4 to 8 mice of each genotype. ${ }^{\star} P<0.05,{ }^{\star \star} P<0.01,{ }^{\star \star \star} P<0.005$

Western blot analysis confirmed the higher Puma expression in the $\mathrm{E} \mu-m y c$ pro-B and $\mathrm{slg}^{+} \mathrm{B}$ cells (Figure $1 \mathrm{~b}$ ) and also indicated that Puma protein levels are higher in $\mathrm{E} \mu$-myc pre-B cells. The increase in Puma protein in the pre-B cells might result from translation of the increased mRNA in the pro-B cells. Unfortunately, we have not identified a suitable antibody for mouse Noxa.

Loss of Puma expanded the B-cell compartment of $\mathbf{E} \boldsymbol{\mu}$-myc mice. No abnormalities in haematopoiesis have been observed in unstressed puma $^{-1-}$ mice, ${ }^{19,20}$ but the $\mathrm{B}$-lineage compartment of pre-malignant $\mathrm{E} \mu$-myc mice is perturbed by increased cell cycling, ${ }^{26}$ which is partially balanced by increased apoptosis. ${ }^{27}$ To determine how the absence of Puma affects haematopoiesis in that context, we enumerated leukocytes in the peripheral blood of young tumour-free animals. E $\mu$-myc/puma ${ }^{-/-}$mice had $\sim 4$-fold more leukocytes than wt non-transgenic littermates and $\sim 3$ fold more than $\mathrm{E}_{\mu-m y c}$ littermates (Figure 2a). This increase was specific to the transgenic mice, as non-transgenic puma $^{-1-}$, puma ${ }^{+/-}$and wt mice all had similar numbers. At 5-6 weeks of age, blood leukocyte levels of $\mathrm{E} \mu-m y c$ mice and $\mathrm{E} \mu-\mathrm{myc}_{\text {puma }}{ }^{+/-}$littermates remained higher than in their non-transgenic counterparts, but the $\mathrm{E} \mu-\mathrm{myc}_{\text {puma }}{ }^{-1-}$ mice had the highest level (Figure 2b). Analysis for B-lymphoid differentiation markers revealed that the leukocyte excess in Puma-deficient $\mathrm{E} \mu$-myc animals reflected an increase in B-lineage cells, as their blood contained several-fold more pro-B/pre-B cells $\left(B 220^{+} \mathrm{slg}^{-}\right)$, virgin $B$ cells $\left(\mathrm{B}^{2} 20^{+} \mathrm{slgM}^{+} \lg \mathrm{D}^{\mathrm{lo}}\right)$ and mature $\mathrm{B}$ cells $\left(\mathrm{B}^{2} 20^{+}\right.$slgM $^{+}$slgD $\left.^{\text {hi }}\right)$ compared with $\mathrm{E} \mu-m y c$ wt mice (Figure 2b). A comparable increase was observed for virgin $B$ cells in the lymph nodes and spleen (Supplementary Figure 1). Accordingly, the pre-malignant $\mathrm{E}_{\mu-m y c / p u m a}{ }^{-1-}$ mice had marked splenomegaly compared with $\mathrm{E} \mu$-myc mice $(P<0.02)$ (Figure 2c), and this must reflect the excess total $B$-lineage cells, because, as expected, loss of Puma on the $\mathrm{E} \mu-m y c$ background did not affect the numbers of $\mathrm{CD}^{+}{ }^{+}$or $\mathrm{CD}^{+} \mathrm{T}$ cells, macrophages, granulocytes or nucleated erythroid progenitors in any tissue examined (data not shown).

We also examined the bone marrow, where $B$ cells develop in adult mice. As reported, ${ }^{26}$ wt $\mathrm{E} \mu-m y c$ bone marrow had around two times as many pro-B and pre-B cells as nontransgenic littermates but fewer $\mathrm{slg}^{+} \mathrm{B}$ cells (Figure $2 \mathrm{~d}$ ). Only the $\mathrm{slg}^{+} \mathrm{B}$ cells (but not the pro-B and pre-B cells) of $\mathrm{E} \mu-\mathrm{myc}$ puma $^{-1-}$ mice were significantly elevated above the levels in wt $\mathrm{E} \mu$-myc mice (Figure 2d).

Puma contributes to Myc-driven apoptosis of pre-B cells. The higher levels of Puma in $\mathrm{E} \mu$-myc B-lymphoid cells (Figure 1) and the modest rise in B-lineage cell numbers 
Pre-B cells
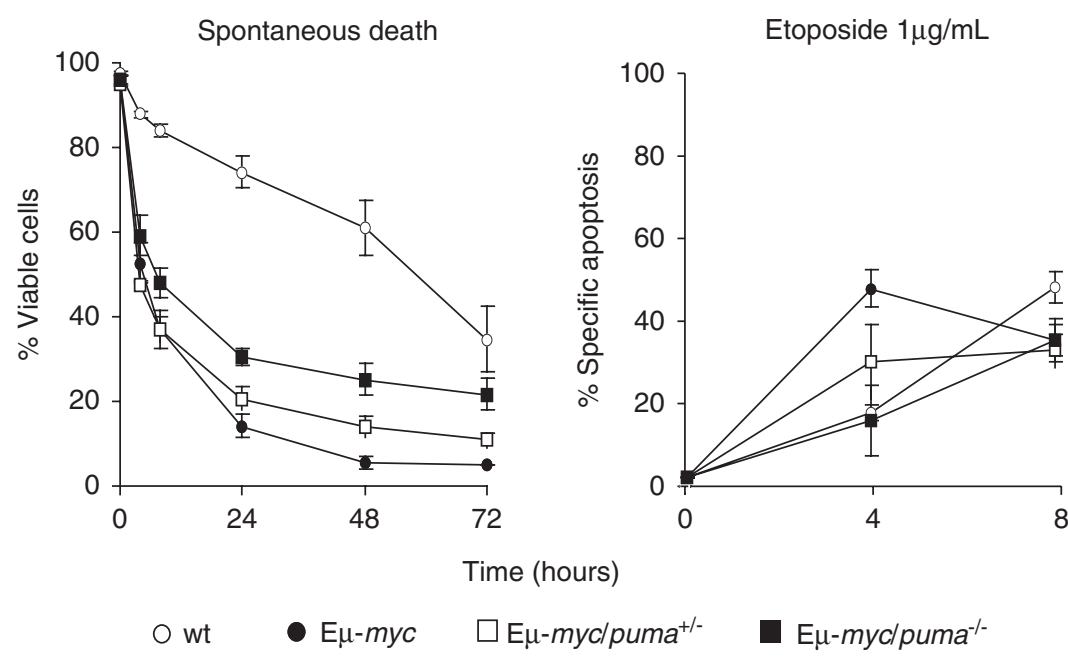

me (hours)

Figure 3 Loss of Puma enhances survival of $\mathrm{E} \mu-m y c$ pre-B cells in culture. Pre-B cells sorted from the bone marrow of 5- to 6-week-old pre-neoplastic wt or $\mathrm{E} \mu$-myc mice of the indicated puma genotypes were cultured in simple medium (no added cytokines) or treated with etoposide $(1 \mu \mathrm{g} / \mathrm{ml})$ for the indicated times. The percentages of viable $\mathrm{E} \mu-m y c /$ puma $^{-l-}$ pre-B cells remaining in culture at 24 and $48 \mathrm{~h}$ were significantly greater than for $\mathrm{E} \mu$-myc pre-B cells $(P<0.01$ and $P<0.001$, respectively). A similar protection was observed for $E \mu$-myc/puma ${ }^{-1-}$ pre-B cells after $4 \mathrm{~h}$ in culture with etoposide, compared with $E \mu$-myc pre-B cells $(P<0.02)$. Values represent means $\pm S$.E.M. of cells from 3 to 6 independent experiments for each genotype

in $\mathrm{E}_{\mu-m y c / p u m a}{ }^{-1-}$ over wt $\mathrm{E} \mu-m y c$ animals (Figure 2) indicated that Puma loss might retard the apoptosis normally induced by c-Myc overexpression. ${ }^{29,30}$ To investigate this, pro-B, pre-B and virgin/mature B cells from young healthy mice were cultured in simple medium (representing cytokine deprivation) or with the DNAdamaging drug etoposide. $\mathrm{E} \mu-m y c / p^{\prime} a^{+/-}$and $\mathrm{E}_{\mu-m y c /}$ puma $^{-/-}$pro-B cells (Supplementary Figure $2 \mathrm{a}$ ) and $\mathrm{slg}^{+} \mathrm{B}$ cells (Supplementary Figure $2 \mathrm{~b}$ ) were no more refractory to either stimulus than their $\mathrm{E} \mu-m y c$ wt counterparts. However, the absence of Puma significantly protected pre-B cells against cytokine deprivation and DNA damage (Figure 3), and the survival of $\mathrm{E} \mu-m y c /$ puma $^{+/-}$pre-B cells was intermediate for cytokine deprivation. The virgin/mature $B$ cells were also tested for their response to cross-linking of the B-cell antigen receptor, but the $\mathrm{E} \mu-m y c / p u m a^{-1-}$ and wt $\mathrm{E} \mu-m y c \mathrm{~B}$ cells died at the same rate (data not shown).

Loss of Puma accelerated B-cell lymphomagenesis in $\mathbf{E} \boldsymbol{\mu}$-myc mice. The effect of Puma on cellularity of the $B$ lineage in $\mathrm{E} \mu-m y c$ mice and on transgenic pre-B-cell survival led us to examine how Puma loss affected lymphomagenesis by monitoring cohorts of $\mathrm{E} \mu$-myc mice of different puma genotypes. $\mathrm{E}_{\mu-m y c}\left(\right.$ puma $\left.^{+/+}\right)$mice $(n=64)$ became ill between 50 and 470 days of age (median 100 days) as reported earlier, ${ }^{25,28}$ and the $\mathrm{E}_{\mu-m y c / p u m a}{ }^{+/-}$mice ( $n=100$ ) succumbed no faster (median 95 days, $P=0.46$; Figure $4 a)$. In contrast, the $\mathrm{E} \mu-m y c /$ puma $^{-1-}$ mice $(n=33)$ had a median survival of 66 days, and all were unwell by 110 days of age, when a quarter of the wt $\mathrm{E} \mu$-myc animals remained healthy $(P<0.0001)$ (Figure 4a). Despite this acceleration, the lymphoma development in $\mathrm{E} \mu-\mathrm{mycl}$ puma $^{-1-}$ mice remained slower than in $\mathrm{E} \mu-m y c / p 53^{+/-}$ animals $(n=23, P<0.0001)$ (Figure $4 \mathrm{a})$.
Sick $\mathrm{E} \mu-m y c /$ puma $^{-/-}$mice presented with enlarged lymph nodes, spleen, and thymus, as in classical $\mathrm{E} \mu$-myc lymphoma. ${ }^{25,28}$ To confirm that the lymphomas were malignant, tumour cells $\left(2 \times 10^{6}\right)$ were injected intra-peritoneally into $\mathrm{C} 57 \mathrm{BL} / 6$ recipients. Five of seven control $\mathrm{E} \mu-m y c$, six of seven $\mathrm{E} \mu-m y c /$ puma $^{+/-}$and seven of eight $\mathrm{E} \mu-m y c /$ puma $^{-/-}$ lymphomas produced tumours in recipients within 11-54 days, comparable to the $90 \%$ transplantability reported earlier for $\mathrm{E} \mu$-myc lymphomas. ${ }^{25,28}$

Immunophenotyping of the primary lymphomas revealed, as expected ${ }^{28}$ that nearly all comprised $\mathrm{B}^{2} 20^{+} \mathrm{slg}^{-}$pro-B/

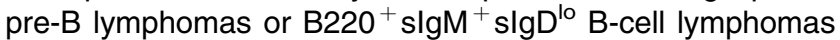
(Supplementary Figures $3 a$ and b), although a small minority contained both $\mathrm{slg}^{-}$and $\mathrm{slg}^{+} \mathrm{B}$ populations (Supplementary Figure $3 c$ ). The puma genotype did not significantly affect the overall proportion of pre-B versus mature B-cell tumours. Pre-B lymphomas comprised $17 / 26,27 / 53$, and $7 / 17$ of the tumours arising in wt, puma ${ }^{+/-}$and puma ${ }^{-/-}$mice, respectively (Figure 4d). Nevertheless, the accelerated morbidity of the $\mathrm{E} \mu-m y c /$ puma ${ }^{-/-}$cohort was due to earlier onset of $\mathrm{slg}^{+} \mathrm{B}$ lymphomas, which arose much sooner than in $\mathrm{E}_{\mu-m y c l}$ puma $^{+/-}$or $\mathrm{E}_{\mu-m y c}$ mice (Figure $4 \mathrm{~b}$ ): median survival was 91 days for $\mathrm{E} \mu$-myc/puma ${ }^{-1-}$ versus 174 days for $\mathrm{E}_{\mu-m y c l}$ puma $^{+/-}$mice $(P<0.001)$. Although $\mathrm{E} \mu-m y c / p u m a^{+/-}$mice also developed $\mathrm{slg}^{+}$B lymphomas slightly earlier than $\mathrm{E}_{\mu-}$ myc mice (whose median survival was 244 days), their overall survival was not significantly impaired. The accelerated disease in the absence of Puma was entirely ascribable to the faster onset of $B$ lymphomas as pre-B lymphomas did not arise earlier in $\mathrm{E} \mu-m y c / p u m a^{-1-}$ mice than control $\mathrm{E}_{\mu-m y c}$ animals (Figure 4c).

Diminished Puma levels enhance leukaemia. Postmortem analysis of tumour-bearing animals revealed that 

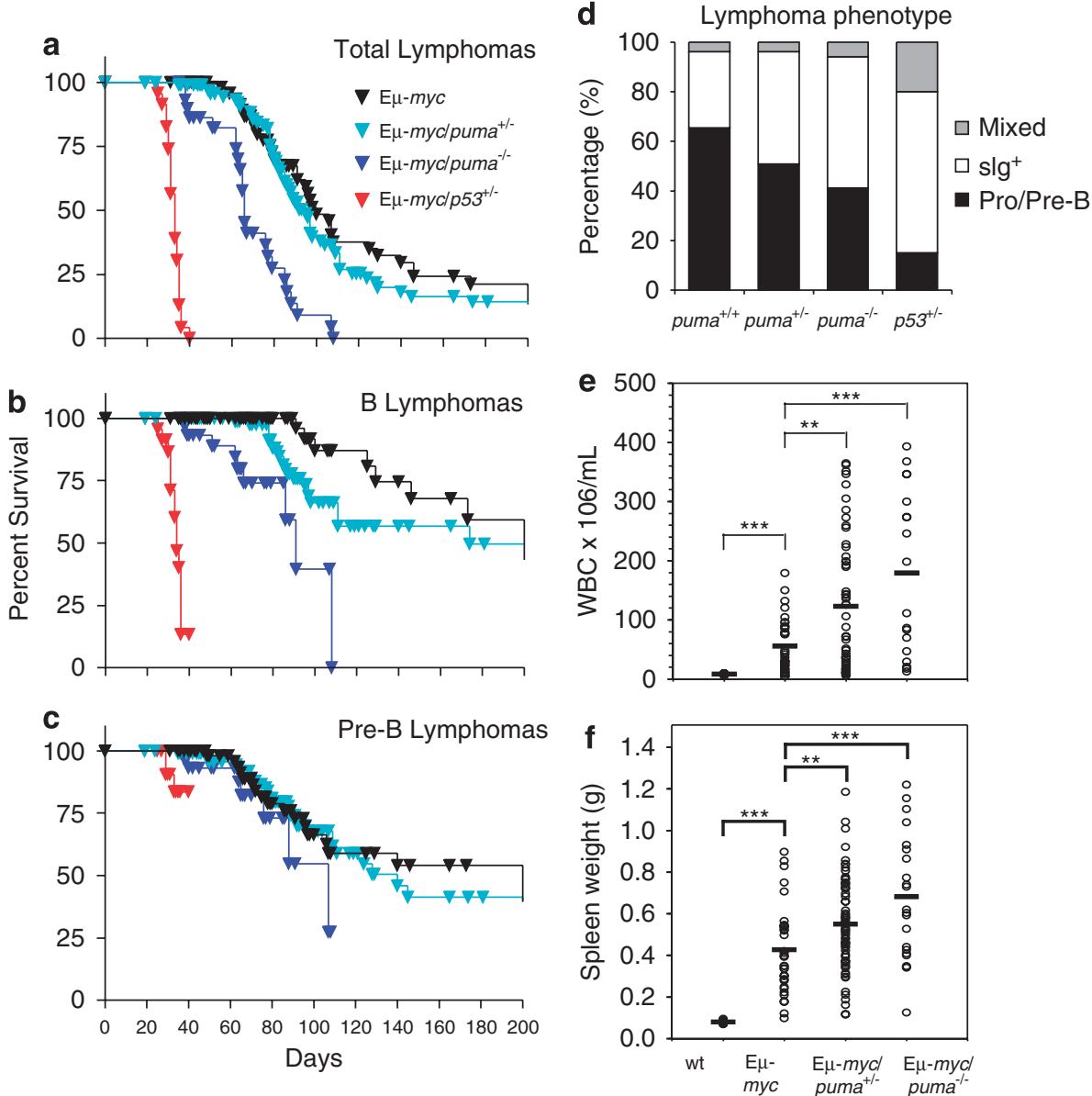

Figure 4 Loss of Puma accelerates lymphoma development in E $\mu$-myc transgenic mice. (a) Kaplan-Meier analysis of tumour-free survival of mice of the indicated genotypes. Lymphomas arose earlier in $\mathrm{E} \mu$-myclpuma ${ }^{-l-}$ mice than in $\mathrm{E} \mu$-myc or $\mathrm{E} \mu$-myc/puma ${ }^{+l-}$ mice $(P<0.001)$. Differences in tumour onset between $\mathrm{E} \mu$-myc and $\mathrm{E} \mu$-myclpuma ${ }^{+1-}$ mice were not significant $(P=0.46)$. (b) B lymphomas arose earlier in $\mathrm{E} \mu-m y c / p u m a^{-1-}$ mice than $\mathrm{E} \mu-m y c$ or $\mathrm{E} \mu-m y c / p u m a^{+l-}$ mice $(P<0.001)$. (c) Pre-B lymphoma development was not accelerated in $\mathrm{E} \mu$-myc mice by loss of one or both puma alleles. (d) Proportions of pro-B/pre-B, mixed and slg ${ }^{+}$lymphomas in ill $\mathrm{E} \mu-\mathrm{myc}, \mathrm{E} \mu-\mathrm{myc} /$ puma $^{+1-}, \mathrm{E} \mu-\mathrm{myc} /$ puma $^{-1-}\left(P=0.07\right.$, trend analysis) and $\mathrm{E} \mu-\mathrm{myc} / \mathrm{p5}^{+1-}$ mice. (e) Numbers of leukocytes (white blood cells: WBC) in the blood of control (healthy) 102-day-old wt C57BL/6 mice and sick $\mathrm{E} \mu$-myc mice of the indicated puma genotypes. Each circle represents a single animal. Bars represent mean leukocyte counts. Numbers of C57BL/6, $\mathrm{E} \mu$-myc, $\mathrm{E} \mu$-myc/puma ${ }^{+/-}$and $\mathrm{E} \mu$-myc/puma ${ }^{-1-}$ mice were 10,33, 54 and 18, respectively. (f) Spleen weights of control 102-day-old (healthy) wt $\mathrm{C} 57 \mathrm{BL} / 6$ mice and sick $\mathrm{E} \mu$-myc mice of the indicated puma genotypes. Bars represent means. Numbers of $\mathrm{C} 57 \mathrm{BL} / 6, \mathrm{E} \mu-\mathrm{myc}, \mathrm{E} \mu-\mathrm{myc}_{\mathrm{p}}$ puma ${ }^{+1-}$ and $\mathrm{E} \mu$-myc/puma ${ }^{-1-}$ mice were $10,34,65$ and 21 , respectively. ${ }^{\star \star} P<0.01,{ }^{\star \star \star} P<0.005$

the absence of Puma, or even loss of one allele, resulted in a higher leukaemic burden than in wt $\mathrm{E} \mu$-myc mice. Although blood leukocyte counts at autopsy varied markedly amongst $\mathrm{E} \mu-m y c / p u m a^{+/-}$and $\mathrm{E} \mu-m y c l$ puma $^{-l-}$ mice, the mean count was $>3$-fold higher for E $\mu$-myc/puma ${ }^{-1-}$ than wt E $\mu$-myc mice $(P<0.005)$ (Figure $4 \mathrm{e})$. Splenomegaly correlated with the extent of leukaemia, spleen weights being 1.6-fold greater in ill $\mathrm{E}_{\mu-m y c / p u m a}{ }^{-1-}$ than ill wt $\mathrm{E} \mu-m y c$ animals. As reported for $\mathrm{E} \mu-\mathrm{myc} / \mathrm{bim}^{-1-}$ mice, ${ }^{10}$ the increased leukaemia in $\mathrm{E} \mu-\mathrm{myc}_{\text {puma }}{ }^{-1-}$ mice occurred exclusively in the setting of $\mathrm{slg}^{+}$B-cell lymphomas: their mean leukocyte numbers were four times that seen in animals succumbing to pre-B cell tumours $\left(209 \pm 125 \times 10^{6} / \mathrm{ml}\right.$ versus $51 \pm 32 \times 10^{6} / \mathrm{ml}$; $P<0.01)$. Leukaemia was also several-fold higher in $\mathrm{E} \mu$-myc/puma ${ }^{+/-}$mice succumbing to $\mathrm{slg}^{+}$B-cell lymphomas compared with those succumbing to pre-B lymphomas (data not shown).
Loss of both Puma and Noxa did not enhance the pre-malignant phenotype more than loss of Puma alone. We have previously shown that functional overlap of Noxa and Puma exists in DNA damage-induced apoptosis of certain cell types, including pro-B/pre-B cells. $^{24}$ We therefore examined whether loss of Noxa, like loss of Puma, had an impact on the $\mathrm{E} \mu-m y c$ mouse model. To do this, we first investigated whether loss of Noxa, alone or together with loss of one or both puma alleles, affected the haematopoietic system of healthy young $\mathrm{E} \mu$-myc mice. On the $\mathrm{E} \mu-m y c$ background, Noxa deficiency alone did not elevate blood leukocytes above the level caused by deregulated Myc expression (Supplementary Figure 4a), affect spleen size (Supplementary Figure 4b) or elevate B-lymphoid cells in the lymph nodes, blood or spleen (Supplementary Figure 4c). In the transgenic bone marrow, however, Noxa loss led to excess total B-lineage cells, pre-B cells and virgin/mature 

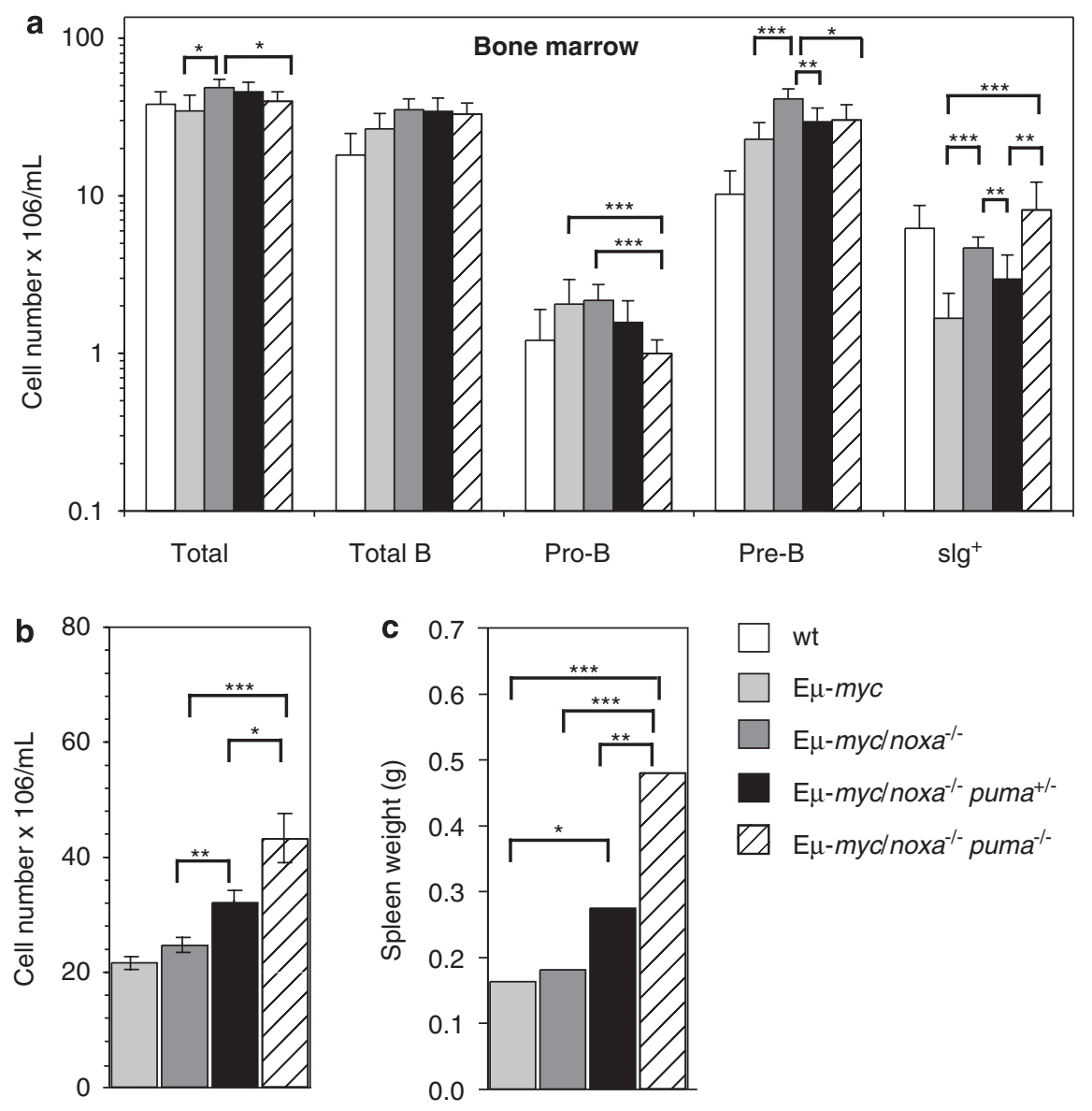

Figure 5 Loss of Noxa did not further augment the elevated leukocytes in pre-malignant $\mathrm{E} \mu$-myc mice lacking one or both puma alleles. (a) Bone marrow cellularity (both femora) and cell subset composition of pre-neoplastic 5- to 6-week-old mice of the indicated genotypes. Values represent means \pm S.E.M. from 5 to 8 mice of each genotype. All differences between non-transgenic and $\mathrm{E} \mu$-myc mice were significant $(P<0.05)$ for total $\mathrm{B}$ cells and pre-B cells; as were comparisons of total $\mathrm{B}$ cells and pro-B cells for wt versus $\mathrm{E} \mu-m y c / n_{n x a}{ }^{-1}$ mice and for mature $\mathrm{B}$ cells for wt versus $\mathrm{E} \mu$-myc and for wt versus $\mathrm{E} \mu$-myc/noxa ${ }^{-1-}$ puma ${ }^{+1-}$ mice. For comparisons of $\mathrm{E} \mu$-myc transgenic mice of the different noxa and puma genotypes, statistically significant differences are indicated. (b) White blood cell counts (means \pm S.E.M.) of pre-neoplastic 4 week-old mice of the

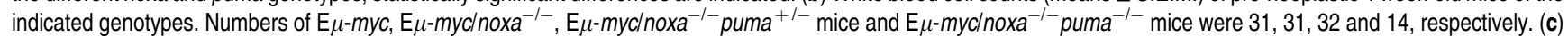
Spleen weights of pre-neoplastic 5- to 6-week-old mice. For B and C, differences between transgenic genotypes were significant as indicated. Values represent means \pm S.E.M. from 5 to 8 mice of each genotype. ${ }^{*} P<0.05,{ }^{* \star} P<0.01,{ }^{* \star *} P<0.005$

$\mathrm{B} 220^{+} \mathrm{slg}^{+} \mathrm{B}$ cells over the wt transgenic populations (Figure 5a).

When loss of Noxa was combined with loss of one allele of Puma, the resulting $\mathrm{E}_{\mu-\mathrm{myc} / \text { noxa }^{-/-} \text {puma }^{+/-} \text {mice }}$ had higher blood leukocyte numbers (Figure $5 b$ ) and greater spleen weights (Figure $5 \mathrm{c}$ ) than $\mathrm{E} \mu-$ myc/noxa $^{-1-}$ animals, and the spleen weights were also significantly higher than those of $\mathrm{E} \mu$-myclpuma ${ }^{+/-}$mice $(P<0.02)$ (compare Figures $2 \mathrm{a}$ and, $\mathrm{c}$ with Figures $5 \mathrm{~b}$ and $\mathrm{c}$ ). $\mathrm{E} \mu-\mathrm{mycl}$ noxa $^{-1-}$ puma $^{+/-}$and $\mathrm{E} \mu-\mathrm{myc} /$ puma $^{+/-}$mice had similar B-lymphoid cell numbers in the bone marrow (Figures $2 \mathrm{~d}$ and 5a) and lymph nodes (Supplementary Figures 1a and 4c) although, perhaps surprisingly, the levels of pre-B and $\mathrm{slg}^{+}$ cells were lower than those in $\mathrm{E} \mu-\mathrm{myc}_{\text {noxa }}{ }^{-1}$ animals (Figure 5c). In the bone marrow, $\mathrm{E} \mu-m y c$ mice deficient for both Noxa and Puma also had fewer immature B cells than in the $\mathrm{E} \mu-m y c /$ noxa $^{-1-}$ mice and strikingly fewer pro-B cells than either the $\mathrm{E} \mu-m y c / n o x a^{-1-}$ or $\mathrm{E} \mu-m y c / p u m a^{-1-}$ mice $(P<0.0001)$ (compare Figure 2d with Figure 5a). The reason for this reduction is not clear.
In contrast, B-cell numbers in the peripheral blood and spleens

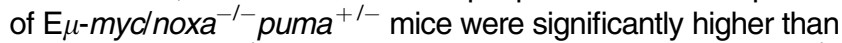
in $\mathrm{E} \mu-m y c / p u m a^{+/-}$mice, but not as high as in $\mathrm{E} \mu-m y c / p u m a^{-1-}$ or $\mathrm{E} \mu-m y c /$ noxa $^{-1-}$ puma ${ }^{-1-}$ mice (compare Figure $2 \mathrm{~b}$ and Supplementary Figure 1 with Supplementary Figure 4c), due to increased pre-B and immature $B$ cells in the peripheral blood (E $\mu$-myclpuma ${ }^{+/-}$versus $\mathrm{E} \mu-m y c /$ noxa $^{-/-}$puma $^{+/-} \quad P<0.02$ and $P<0.01$ ) and immature $B$ and mature $B$ cells in the spleen (E $\mu$-myclpuma ${ }^{+/-}$versus $\mathrm{E} \mu-m y c /$ noxa $^{-1-}$ puma $^{+/-} \quad P<0.02$ and $P<0.04)$. E $\mu-m y c /$ noxa ${ }^{-1-}$ puma $^{-1-}$ mice had more mature $\mathrm{B}$ cells in peripheral blood $(P<0.03)$ and spleen $(P<0.05)$ than

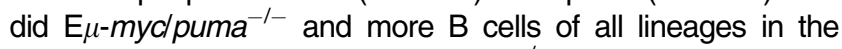
peripheral blood than did $\mathrm{E} \mu-m y c / n o x a^{-1-}$ mice (Supplementary Figure 4c).

The elevated levels of noxa mRNA in $\mathrm{E} \mu$-myc B-lymphoid cells (Figure 1a) and the increased cell numbers within bone marrow B-cell subsets provoked by Noxa loss suggested that loss of Noxa, like that of Puma, might retard the apoptosis normally induced by c-Myc. Survival assays with FACSpurified sub-populations, however, showed that the absence 
of Noxa alone did not protect cells at any stage of B-cell development against either cytokine deprivation or etoposide, compared with cells from $\mathrm{E} \mu-m y c$ or $\mathrm{E} \mu-\mathrm{myc}_{\text {puma }}{ }^{+/-}$mice (Supplementary Figure 5). This is in contrast to loss of Puma, where protection relative to $\mathrm{E} \mu-m y c$ was significant (Figure 3). B-lymphoid cells from $\mathrm{E}_{\mu-\mathrm{myc}}$ noxa ${ }^{-1-}$ puma $^{-1-}$ mice did not survive better in culture than those from $\mathrm{E}_{\mu-m y c / p u m a^{-1-}}$ mice.

\section{Combined loss of Noxa and Puma in $\mathrm{E} \mu$-myc mice} accelerated pre-B as well as B-lymphomagenesis. The overlapping roles of Noxa and Puma in DNA damageinduced apoptosis of pro-B/pre-B cells ${ }^{24}$ indicated to us that Noxa and Puma might cooperate to limit Myc-induced lymphomagenesis. We first investigated whether loss of Noxa alone could promote lymphomagenesis, by monitoring cohorts of $\mathrm{E} \mu-m y c / n o x a^{+/-}$and $\mathrm{E} \mu-m y c / n o x a^{-/-}$mice. Loss of Noxa alone had little effect. The median survival of E $\mu-m y c /$ noxa $^{+/-} \quad(n=76), \quad \mathrm{E} \mu-m y c /$ noxa $^{-1-} \quad(n=56)$ and $\mathrm{E} \mu-m y c(n=64)$ animals was very similar (Supplementary Figure 6). Indeed, tumour development in the absence of Noxa actually delayed onset of pre-B lymphomas $(P<0.05$, Figure 6c), for unknown reasons.

Next, cohorts of Noxa-deficient $\mathrm{E} \mu$-myc transgenic mice lacking one or both alleles of puma were monitored, to investigate if a role for Noxa in tumour suppression might become evident when combined with Puma deficiency. Strikingly, $\mathrm{E}_{\mu-m y c / n o x a^{-1-}}$ puma $^{+/-}$mice $(n=29)$ succumbed to lymphoma with a median survival of 77 days (Figure 6a), a rate significantly faster $(P<0.0001)$ than that seen in $\mathrm{E} \mu$-myc/puma ${ }^{+/-}$mice (median survival 95 days, Figure 4a). Indeed, the rate approached that observed with $\mathrm{E} \mu$-myc/puma ${ }^{-1-}$ mice (Figure $4 \mathrm{a}$ ). In contrast, the loss of one allele each of noxa and puma did not appreciably alter survival compared to loss of one puma allele alone (median survival 91 days, $n=13$, data not shown). Loss of both the puma and the noxa alleles (E $\mu-m y c /$ noxa ${ }^{-1-}$ puma $^{-1-}$ mice) further accelerated tumour onset (median survival 65 days, $n=11$ ) over that in $\mathrm{E} \mu-m y c / n o x a^{-1-}$ puma ${ }^{+/-}$mice $(P<0.04)$, albeit not significantly faster than in $\mathrm{E} \mu-m y c / p u m a^{-1-}$ mice $(P=0.12)$. The accelerated tumorigenesis in $\mathrm{E}_{\mu-\text { myc/noxa }}{ }^{-1-}$ puma ${ }^{+/-}$ and $\mathrm{E} \mu-\mathrm{myc}_{\text {noxa }}{ }^{-1-}$ puma $^{-1-}$ mice involved both the pre-B and B-cell compartments (Figures 6B and C). Thus, Noxa has a role in restraining Myc-induced lymphomagenesis, albeit less substantial than that of Puma.

Although Noxa loss alone did not affect development of B-cell lymphomas, on a puma heterozygous background Noxa loss significantly accelerated B-cell lymphoma onset (median survival 86 days) compared with puma heterozygosity alone (median survival 174 days; $P<0.01$ ) (Figure $6 \mathrm{~b}$ ). Curiously, although Noxa loss alone actually delayed pre-B lymphoma development $(P<0.05)$, additional loss of one puma allele accelerated pre-B lymphoma onset (Figure $6 \mathrm{c}$ ),

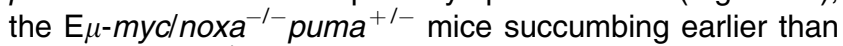
$\mathrm{E} \mu$-myc/puma ${ }^{+/-}$mice (median survival 93 versus 140 days; $P<0.02)$. Notably, E $\mu-m y c /$ noxa ${ }^{-I-}$ puma $^{-1-}$ mice also succumbed to pre-B lymphomas significantly earlier than $\mathrm{E} \mu-\mathrm{myc}_{\text {puma }}{ }^{-1-}$ mice (median survival 71 versus 107 days; $P<0.02$ ) (compare Figure $6 \mathrm{c}$ with Figure $4 \mathrm{c}$ ). The proportion of pre-B versus $\mathrm{slg}^{+} \mathrm{B}$-cell tumours arising in
$\mathrm{E}_{\mu-\mathrm{myc}}$ puma ${ }^{+/-}$and $\mathrm{E} \mu-m y c / p u m a^{-1-}$ was not, however, affected by additional loss of noxa (Figure 6d).

In contrast to Puma loss, Noxa loss did not increase the leukaemic burden in $\mathrm{E} \mu$-myc mice. The mean white blood cell counts and spleen weights at autopsy for ill $\mathrm{E} \mu$-myc/noxa ${ }^{+/-}$ (not shown) and $\mathrm{E} \mu-\mathrm{myc}_{\text {noxa }}{ }^{-1-}$ mice (Figure $6 \mathrm{e}$ and f) were not significantly greater compared with their ill $\mathrm{E} \mu-m y c$ counterparts. Although killed $\mathrm{E} \mu-\mathrm{myc}_{\text {noxa }}{ }^{-/-}$puma $^{+/-}$mice had spleen weights and blood leukocyte numbers similar to $\mathrm{E}_{\mu-\mathrm{myc}}$ puma $^{-1-}$ mice (compare Figures $4 \mathrm{e}$ and $\mathrm{f}$ with Figures $6 e$ and $f$ ), loss of the second puma allele on the Noxa-deficient background provoked no greater increase.

Loss of heterozygosity for puma is not required for E $\mu$-myc-induced lymphomagenesis. The faster tumour onset in $\mathrm{E} \mu-m y c / n o x a^{-1-}$ puma $^{+1-}$ than $\mathrm{E} \mu-m y c /$ puma $^{-1-}$ mice could be due simply to the absence of noxa, but it might instead reflect loss of the remaining puma allele. To distinguish between these possibilities, we performed allelespecific PCR for puma on 12 randomly selected $\mathrm{E}_{\mu-\mathrm{myc}}$ noxa ${ }^{-1-}$ puma ${ }^{+1-}$ tumours. All retained the wt puma allele (Figure 7a). To rule out the possibility that the wt puma allele had been amplified from normal stromal tissue contaminating the lymphoma specimen, four tumours were FACS-sorted for large $\mathrm{B}_{2} 20^{+}$lymphoma cells. The allele-specific PCR yielded the same result (Figure $7 \mathrm{~b}$ ). Western blotting of eight $\mathrm{E} \mu-\mathrm{myc}$ noxa ${ }^{-1-}$ puma $^{+/-}$tumours tested revealed Puma protein (Figure 7c), also arguing against loss of heterozygosity. Interestingly, however, the Puma levels were markedly reduced in several tumours (e.g., no. 15, 34 and 42 in Figure 7c). This suggests that Myc-induced lymphomagenesis sometimes selects for reduced Puma expression, at transcriptional and/or post-transcriptional levels.

\section{Loss of Puma but not loss of Noxa reduced selection for} a mutated p53 pathway in $E \mu-m y c$ lymphoma. To investigate whether lymphomas from $\mathrm{E}_{\mu}$-myc/puma ${ }^{-1-}$ mice differed from control $\mathrm{E} \mu$-myc lymphomas in their need to select for mutations in the p19Arf/p53 pathway, the p53 pathway status of randomly selected tumours was examined in several ways: from the levels of p19Arf protein (as p53 normally downregulates p19Arf expression by a negative feedback loop ${ }^{33}$ ), the presence or deletion of the Ink4a/Arf locus by genomic PCR, ${ }^{36}$ the level of p53 protein (high levels indicating mutant, stabilised p53 protein) and the sequencing of exons 4-10 of the p53 gene. High levels of p19Arf, indicative of loss of p53 function due to impaired negative regulation $^{37}$ (Figure 8a), were noted in 3/23 $\mathrm{E} \mu$-myc, 2/12 $\mathrm{E} \mu$ myclpuma $^{+/-}, 3 / 10 \mathrm{E} \mu-m y c / n o x a^{-1-}$ and 2/8 $\mathrm{E} \mu-m y c / n o x a^{-/-}$ puma $^{+/-}$lymphomas (Figure $8 \mathrm{~b}$ and Supplementary Figure 7 and 8 and data not shown). Although none of the $15 \mathrm{E} \mu-\mathrm{mycl}$ puma $^{-1-}$ lymphomas tested exhibited high p19Arf levels, 1 of $9 \mathrm{E} \mu-m y c / n_{\text {noxa }}{ }^{-1}$ puma $^{-1-}$ lymphomas (no. 104 in Supplementary Figure 7) had a clear mutant p53 phenotype, as evidenced by high levels of both the Arf and p53 proteins. A lower level of p19Arf was found in a few tumours (e.g., no. 291, 211 and 362 in Figure 8b); we think the sensitivity of the antibody used allowed detection of Arf upregulation by oncogenic stress in the absence of loss of p53 function, ${ }^{38}$ as those tumours retained wt p53 function by all other criteria. 
a

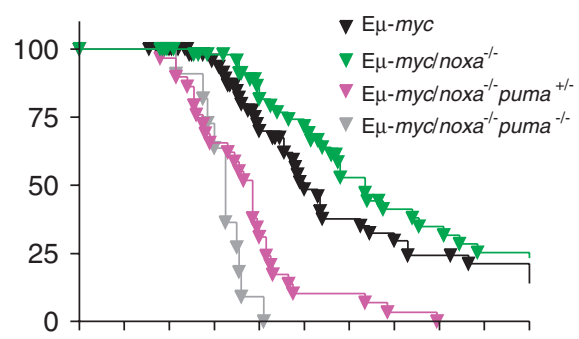

b

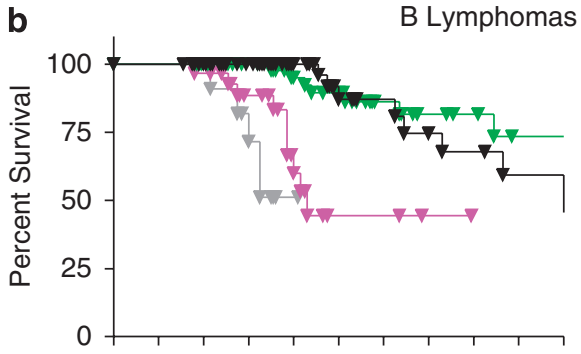

C

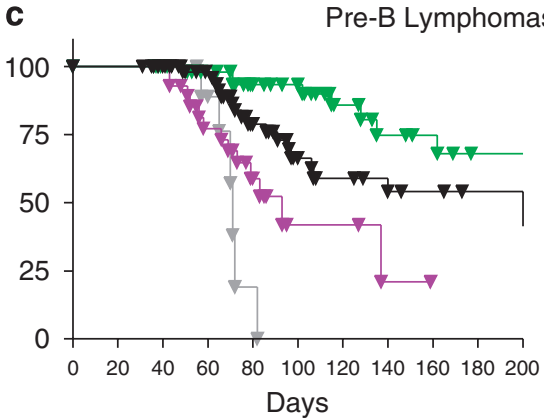

d Lymphoma phenotype
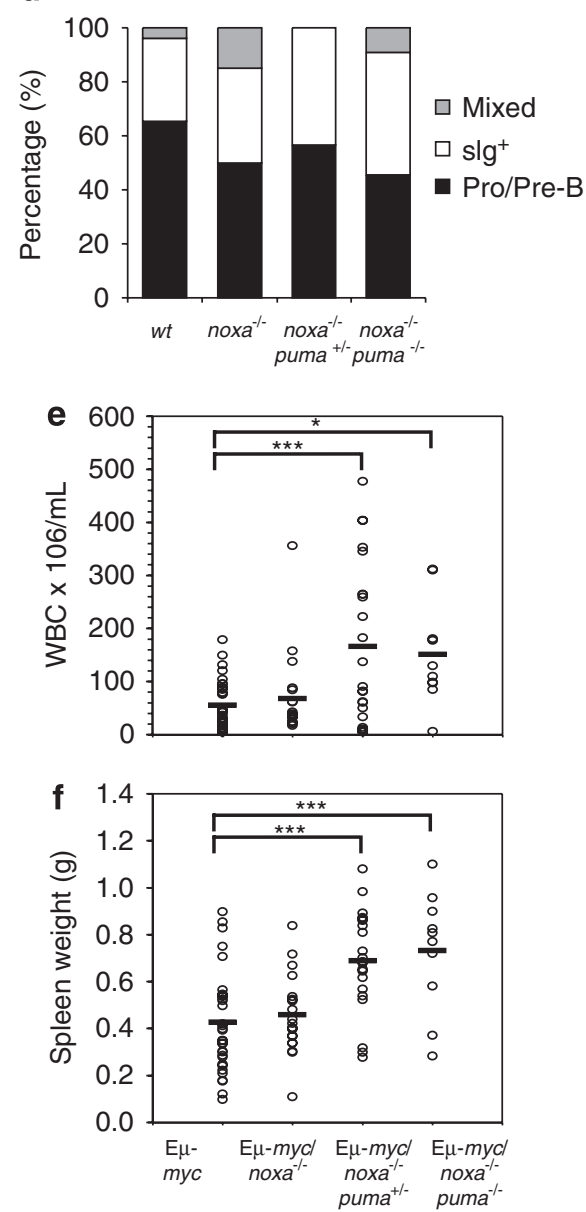

Figure 6 Loss of Noxa accelerates lymphoma development in $\mathrm{E} \mu$-myclpuma ${ }^{+/-}$mice. (a) Kaplan-Meier analysis of tumour-free survival of mice of the indicated genotypes. Lymphomas developed earlier in $\mathrm{E} \mu$-myclnoxa ${ }^{-1-}$ puma $^{-1-}(n=11)$ than $\mathrm{E} \mu$-myc/noxa ${ }^{-1-}$ puma ${ }^{+/-}(n=29)$ mice $(P<0.04)$ and both arose earlier than in $\mathrm{E} \mu$-myc mice $(n=64)(P<0.0001)$. (b) B lymphomas arose earlier in $\mathrm{E} \mu-$-myclnoxa ${ }^{-1-}$ puma ${ }^{+/-}$than $\mathrm{E} \mu$-myclpuma ${ }^{+/-}$mice (compare with Figure $\left.4 ; P<0.01\right)$. (c) Pre-B

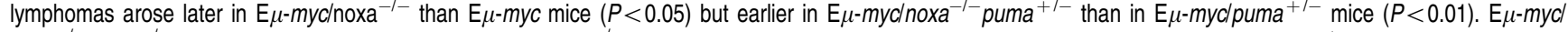
noxa ${ }^{-l-}$ puma $^{-1-}$ mice succumbed earlier than $\mathrm{E} \mu$-myclpuma ${ }^{-l-}$ mice (compare to Figure $4 \mathrm{c} ; P<0.02$ ). (d) The proportions of pre-B, slg ${ }^{+}$and mixed pre-B/B-cell lymphomas arising in $\mathrm{E} \mu-\mathrm{myc} / \mathrm{puma}^{+/-}$and $\mathrm{E} \mu-\mathrm{myc} / \mathrm{puma}^{-1-}$ were not affected by additional loss of Noxa. (e) White blood cell numbers in sick $\mathrm{E} \mu-\mathrm{myc}$ mice of the indicated noxa and puma genotypes. Each circle represents a single animal. Bars indicate means. Numbers of $\mathrm{E} \mu-\mathrm{myc}, \mathrm{E} \mu-\mathrm{myc} /$ noxa $^{-1-}, \mathrm{E} \mu-\mathrm{myc} /$ noxa $^{-l-}$ puma ${ }^{+1-}$ mice and $\mathrm{E} \mu-\mathrm{myc}_{\text {noxa }}{ }^{-1-}$ puma $^{-1-}$ mice were 33, 20, 23 and 10, respectively. (f) Spleen weights of sick mice of the indicated genotypes. Bars indicate means. Numbers of E $\mu$-myc, $\mathrm{E} \mu-m y c / n o x a^{-l-}, \mathrm{E} \mu-m y c / n o x a^{-1-}$ puma $^{+l-}$ mice and $\mathrm{E} \mu-m y c / n o x a^{-l-}$ puma $^{-l-}$ mice were $34,21,22$ and 10, respectively. ${ }^{*} P<0.05,{ }^{* * *} P<0.005$

Six lymphomas lacking Puma alone were examined in most detail. None of them expressed a high level of p53 protein (Figure 8c), had a p53 mutation detectable by sequencing or had deleted the Ink4A/Arf locus (Supplementary Figure 8 and data not shown). In addition, none of the 11 cell lines derived from $\mathrm{E}_{\mu}$-myc/puma ${ }^{-/-}$lymphomas were refractory to treatment with etoposide, as was, in contrast, the known p53 mutant lymphoma, $\mathrm{E}_{\mu-m y c / n o x a^{-/-}}$puma $^{-/-}$no. 104 (Supplementary Figure 8 and data not shown). Thus, although the absence of Puma does not totally ablate the selection for mutations in the p53 pathway, it appears to substantially reduce it.

\section{Discussion}

Although the BH3-only protein Puma and, to a lesser extent, Noxa, are crucial for apoptosis mediated by the tumour suppressor p53, mice deficient for noxa or puma, ${ }^{19,20,22}$ or even both, ${ }^{24}$ have not proven prone to tumour development. Nonetheless, we reasoned that Puma and Noxa might constrain tumour development in the context of an oncogenic lesion that promotes apoptosis. As the major barrier to Myc-induced lymphomagenesis is thought to be Myc-induced apoptosis, which acts predominantly through the p19Arf-p53 pathway, regulated by the $\mathrm{Bcl}-2$ protein family, ${ }^{32}$ we have explored whether loss of Puma and/or Noxa could substitute for p53 loss in accelerating Myc-induced lymphomagenesis.

Consistent with a role in mediating Myc-induced apoptosis, puma and noxa mRNA expression levels were elevated in pro-B and mature $\mathrm{B}$ cells from $\mathrm{E} \mu-m y c$ mice, albeit not in pre-B cells. Two pathways for induction of apoptosis by c-Myc have been identified. In the better-studied path, c-Myc induces p19Arf expression, and p19Arf in turn prevents the degradation of $p 53$ by sequestering its ubiquitin ligase, Mdm2. ${ }^{31,37}$ The resulting elevated p53 level induces transcription of noxa 


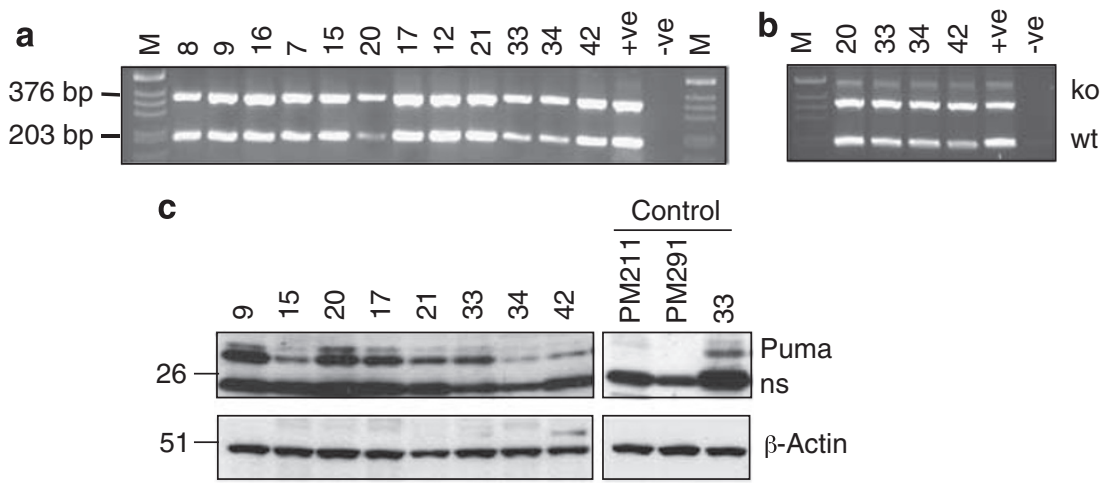

Figure 7 Tumours from $\mathrm{E} \mu-\mathrm{myc} /$ noxa $^{-1-}$ puma ${ }^{+/-}$mice retain the wt puma allele but some exhibit reduced levels of Puma expression. Allele-specific PCR for retention of the residual wt puma allele was performed on (a) 12 randomly selected tumours from $\mathrm{E} \mu$-myc/noxa ${ }^{-1-}$ puma ${ }^{+/-}$mice and (b) lymphoma cells sorted from four $\mathrm{E} \mu$-mycl noxa ${ }^{-1}$ puma $^{+1-}$ mice based on large forward scatter and staining for B220. The wt and knockout puma alleles are 203 and $376 \mathrm{bp}$, respectively. A positive control for puma heterozygosity $(+\mathrm{ve})$ and a no-DNA control $(-\mathrm{ve})$ were included. (c) Western blot analysis of Puma and $\beta$-actin (loading control) in randomly selected E $\mu$-mycl

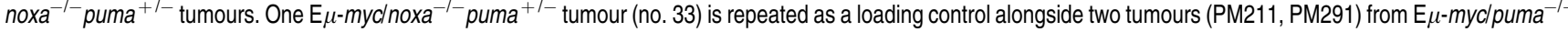
mice, in which no Puma could be detected. The anti-Puma antibody also detects a non-specific band (ns). Protein size standards in $\mathrm{kDa}$ are indicated on the left

and puma, ${ }^{15-17}$ which most likely explains the elevated levels of noxa and puma mRNA and of Puma protein produced by Myc. However, at least in bone marrow-derived B-lymphoid cells $^{35}$ c-Myc can also induce apoptosis by a p19Arf- and p53-independent mechanism, ${ }^{39}$ mediated in part by induction of Bim, ${ }^{10}$ as well as repression of anti-apoptotic $\mathrm{Bcl}-\mathrm{x}_{\mathrm{L}}{ }^{34}$ and Bcl-2. ${ }^{10}$ Theoretically, c-Myc might also enhance Puma and Noxa expression by this second pathway.

Loss of Puma impaired the Myc-induced apoptotic programme. Puma loss protects diverse cell types, including $B$ lymphocytes, against a range of apoptotic stimuli both in vitro ${ }^{19,20}$ and in vivo. ${ }^{21,24}$ Pertinently, Puma loss rendered growth factor-deprived myeloid progenitor cells refractory to c-Myc-induced apoptosis in culture. ${ }^{20}$ Consistent with this, compared with $\mathrm{E} \mu$-myc (wt) cells, $\mathrm{E} \mu-m y c$ pre-B cells deficient for Puma were partially protected from spontaneous death in vitro (cytokine deprivation) and presumably also in vivo.

In accordance with the enhanced survival of $\mathrm{E} \mu-\mathrm{myc} /$ puma $^{-1-}$ pre-B cells in vitro, pre-malignant $\mathrm{E} \mu-m y c / p u m a^{-/-}$ mice had more pre-B cells in their peripheral blood than did control $\mathrm{E} \mu-m y c$ animals. In addition, the number of mature $\mathrm{B}$ cells in the bone marrow was increased, consistent with the acceleration in B-lymphoma development observed in $\mathrm{E} \mu-\mathrm{myc}_{\text {puma }}{ }^{-1-}$ mice. Lastly, pre-B cells lacking Puma were partially protected from DNA damage-induced death. Conversely, Noxa-deficient pre-neoplastic $\mathrm{E} \mu$-myc mice exhibited excess pre-B and $B$ cells in the bone marrow, but these cells did not survive better in vitro with the stimuli tested and the increase in the bone marrow was not associated with acceleration in either pre-B or B-cell lymphoma. These findings suggest that the number of $B$-lymphoid cells present in the pre-malignant state need not correlate with the rate of tumour onset. Consistent with this idea, $\mathrm{E} \mu$-myc mice deficient for Bcl-2 had much fewer B-lymphoid cells but developed lymphomas as rapidly as wt $\mathrm{E} \mu-m y c$ mice ${ }^{40}$ Loss of Puma may accelerate $\mathrm{E} \mu$-myc-induced lymphomagenesis not only by increasing the number of target cells but also by prolonging the survival of small numbers of pre-B cells subjected to limiting cytokine conditions and/or oncogenic stress, thereby increasing their chance acquisition of oncogenic lesions that cooperate with Myc in neoplastic transformation. As more Puma-deficient mice succumbed to $\mathrm{slg}^{+} \mathrm{B}$ lymphomas than pre-B lymphomas, Puma loss may preferentially allow inappropriate cell survival at the pre-B to $\mathrm{slg}^{+} \mathrm{B}$-cell transition.

puma heterozygosity increased tumour burden but did not hasten tumour onset. Loss of one puma allele was not sufficient to accelerate tumour onset significantly, even for B lymphomas. This was somewhat surprising, given the significant protection from apoptosis afforded by haploinsufficiency of puma in lymphoid cells ${ }^{19-21}$ and the finding that a shRNA construct, which diminished but did not abolish Puma expression, accelerated lymphomagenesis in lethally irradiated mice reconstituted with fetal liver-derived stem cells from $\mathrm{E} \mu$-myc mice. ${ }^{11}$ Although the level of puma knockdown achieved may have exceeded $50 \%$, it is also possible that c-Myc-induced lymphomagenesis in irradiated, reconstituted mice is more sensitive to Puma dosage than that in unmanipulated $\mathrm{E} \mu-m y c$ mice. Puma knockdown might, for example, have enhanced survival of fetal liver stem cells during the in vitro infection period with the shRNA retrovirus, thereby facilitating more rapid lymphomagenesis in the transplant recipients.

Interestingly, ill $\mathrm{E} \mu-m y c / p u m a^{-1-}$ mice and even some $\mathrm{E}_{\mu-\mathrm{myc}}$ /puma ${ }^{+/-}$mice exhibited higher levels of leukaemia and splenomegaly than those seen in ill wt $\mathrm{E} \mu-m y c$ mice. As lymphoma/leukaemia cells in wt $\mathrm{E}_{\mu}$-myc mice exhibit spontaneous apoptosis, ${ }^{36}$ Puma must play a critical role in the death of these cells in vivo and thereby limit their accumulation. However, the increased leukaemia and spleen size in sick $\mathrm{E} \mu$-myc/puma ${ }^{+/-}$mice did not lead to significantly earlier deaths compared with $\mathrm{E} \mu-m y c(w t)$ mice.

Puma delayed the onset and limited the tumour burden of B-cell lymphoma in $\mathrm{E} \mu$-myc mice. Pre-B lymphomas predominate in wt $\mathrm{E} \mu$-myc mice ${ }^{10,28}$ but Puma deficiency, like loss of $\mathrm{Bim}^{10}$ or loss of one allele of $p 53$, favoured the 

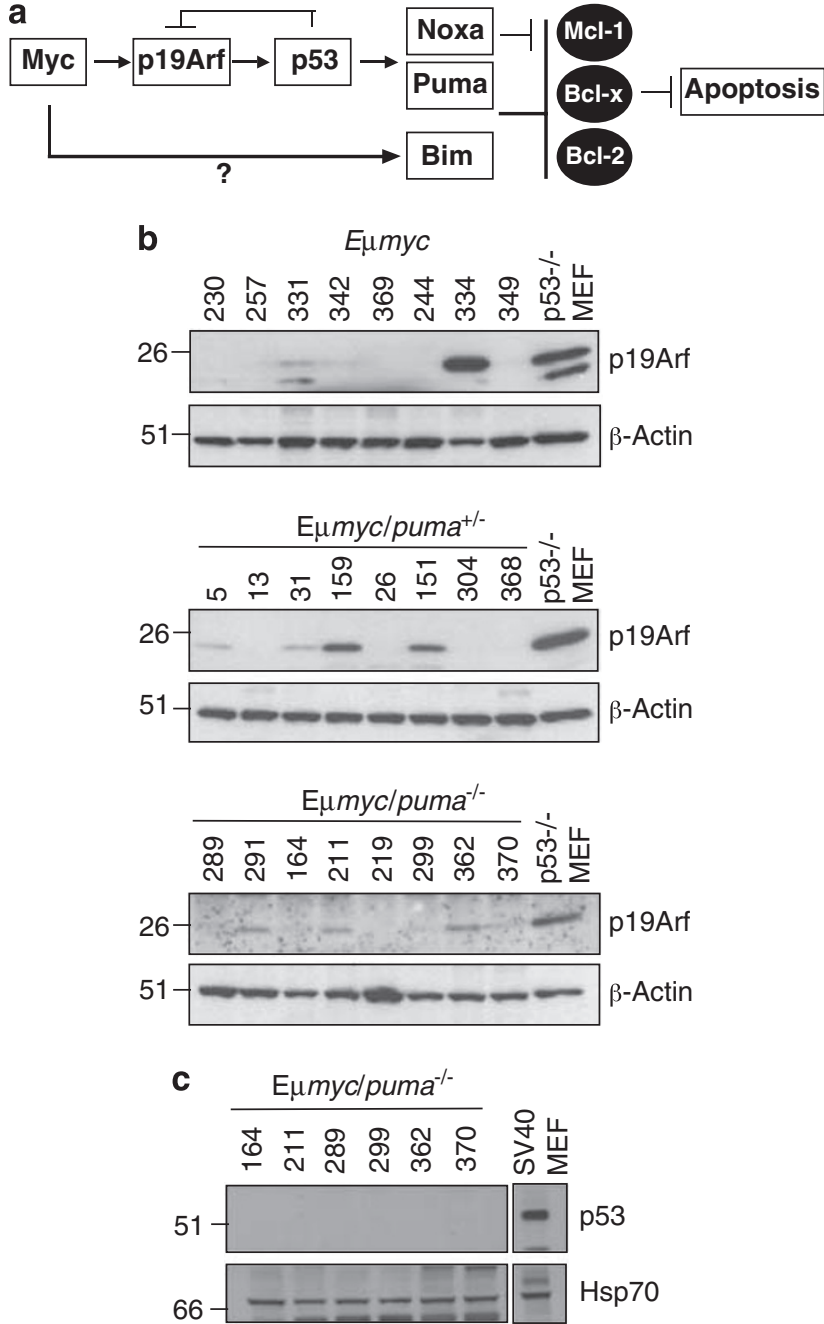

Figure 8 Model for Myc-induced apoptosis and detection of alterations in the p53 pathway. (a) The diagram depicts two pathways by which Myc engages the core apoptotic machinery, one through p19Arf, p53 and Puma and Noxa, and the other through Bim (modified from Egle et al. ${ }^{10}$ ). Western blot analysis of (b) p19Arf and $\beta$-actin (loading control), or (c) p53, and Hsp70 (loading control) in randomly selected $\mathrm{E} \mu$-myc lymphomas of the indicated puma genotypes. $p 53^{-1-}$ mouse embryonic fibroblasts (MEF) or MEF immortalised with SV40 large T antigen, were included as positive controls for p19Arf overexpression and p53 overexpression, respectively. In (c) the MEF control was run on the same gel but a lane not required was spliced out of this gel. Protein size standards in $\mathrm{kDa}$ are indicated on the left

development of $\mathrm{slg}^{+} \mathrm{B}$ lymphomas, which arose much earlier in the $\mathrm{E} \mu-m y c /$ puma $^{-/-}$mice. Unlike Bim, ${ }^{10}$ however, Puma proved not to be important for apoptosis at the B-cell receptor checkpoint, as loss of Bim but not of Puma protected against killing by cross-linking of the B-cell antigen receptor.

Thus, despite the marked similarities of loss of Bim and loss of Puma on Myc-induced lymphomagenesis - both yielding more rapid $\mathrm{slg}^{+}$B lymphomas with associated leukaemia slightly different stages of development may be affected. The increased Puma protein levels at the pre- $B$ stage may suggest that Puma plays a role at the pre-B to $B$ checkpoint. At that developmental stage, the process of Ig light chain gene rearrangement, which requires DNA breakage, may both predispose the cells to acquire oncogenic mutations and render them sensitive to Puma-mediated apoptosis. The predominant mature B-cell immunophenotype of Pumadeficient tumours in this study contrasts with the report that tumours arising in mice receiving shRNA-mediated knockdown of either puma or p53 were pre-B lymphomas, but the phenotype of only three lymphomas of each genotype was reported and the pre-B compartment in that system might be more vulnerable to Puma knockdown. ${ }^{11}$

Noxa and Puma can cooperate to affect tumour onset in both pre-B and B cells. It is not surprising that Puma generally has a greater role in apoptosis than Noxa, because Puma (like Bim) can engage and inactivate all of the pro-survival Bcl-2 family members, whereas Noxa antagonises only $\mathrm{Mcl}-1$ and $\mathrm{A} 1{ }^{41,42}$ Nevertheless, the functional overlap of Noxa and Puma in DNA damageinduced apoptosis of certain cell types, including pro-B/pre-B cells, ${ }^{24}$ indicated that Noxa and Puma might cooperate in suppressing Myc-induced lymphomagenesis. This did indeed occur to a significant extent, as the loss of Noxa on a puma ${ }^{+/-}$ background accelerated $\mathrm{E} \mu$-myc-induced lymphomagenesis almost as much as loss of both puma alleles. Moreover, loss of both Puma and Noxa accelerated the development of pre-B as well as mature B-cell tumours. As loss of Puma alone did not accelerate development of pre-B lymphoma, Noxa must contribute at least in the pro-B/pre-B compartment to tumour suppression. It is possible that when Puma function is compromised, for example in pre-malignant $\mathrm{E} \mu-m y c /$ puma $^{-1-}$ B-lineage cells, the levels and/or activation state of Noxa are heightened. Their synergy was illustrated by step-wise increases in B-cell subsets in the peripheral blood observed with loss of one or both alleles of puma on a Noxa-deficient background.

The accelerated tumour onset in $\mathrm{E} \mu-\mathrm{myc} /$ noxa $^{-1-}$ puma $^{+/-}$ mice was not accompanied by increased leukaemia/lymphoma burden, as spleen size and leukocyte numbers resembled those in $\mathrm{E} \mu-\mathrm{myc} /$ puma $^{+/-}$mice. As we found no evidence that the acceleration was associated with loss of the remaining puma allele in $\mathrm{E} \mu-m y c / n o x a^{-1}$ puma ${ }^{+/-}$mice, loss of one allele of puma and both noxa alleles may reach a threshold of apoptosis resistance sufficient for tumorigenesis. Nevertheless, the markedly low Puma protein level observed in a number of tumours with a single puma allele may well indicate that tumorigenesis can select for suppression of expression from that allele at the transcriptional and/or post-transcriptional level. ${ }^{43}$

It is curious that although Noxa deficiency accelerated Myc-driven lymphoma development in a Puma heterozygous background, Noxa deficiency in a Puma wild-type background appeared to delay the onset of at least the pre-B tumours. At present the basis for this difference is unknown, as Noxa and Puma both function at least primarily by engaging pro-survival family members, albeit with overlapping specificity. The fact that Noxa and Puma can be regulated in multiple ways might be relevant. We do not think the differing impact of Noxa deficiency on tumorigenesis reflects some compensation between Noxa and Puma, because we have previously reported ${ }^{24}$ that loss of Puma had no impact on the expression of Noxa or three other BH3-only proteins (Bim, Bad or Bid) and 
that, conversely, loss of Noxa has no impact on the expression of Puma, Bad, Bim or Bid, in either unstressed lymphoid cells or those exposed to two apoptotic stimuli. Furthermore, we are aware of no reported evidence for compensating changes in expression of BH3-only proteins in other systems.

\section{Loss of both Noxa and Puma was not equivalent to loss of p53 in lymphomagenesis but loss of Puma did reduce} selection for p53 loss. Clearly, neither loss of Puma, nor even loss of both Noxa and Puma, accelerated E $\mu$-mycinduced lymphomagenesis as much as loss of even one allele of p53. Interestingly, shRNA-mediated knockdown of puma accelerated retroviral c-Myc-induced lymphoma development as potently as did knockdown of $p 53,{ }^{11}$ perhaps due to differences in that experimental system (see Discussion above). Pertinently, in response to stimuli that activate p53, the puma knockdown cells underwent $\mathrm{G} 1$ cell cycle arrest normally, ${ }^{11}$ consistent with the notion that Puma mediates p53's apoptotic action but not its cell cycle arrest function. ${ }^{11,16,17}$ Collectively, these findings indicate that the pro-apoptotic activity of p53 is only one of the ways it safeguards against tumour development. Its roles in cell cycle arrest, DNA repair and cellular senescence are likely to contribute to tumour suppression. ${ }^{1}$

We assessed the functionality of the p53 pathway in the lymphoma cells from the levels of p19/Arf protein (as p53 normally downregulates p19/Arf expression by a negative feedback loop $^{33}$ ), the presence of the Ink4a/Arf locus by genomic $\mathrm{PCR}^{36}$ the level of p53 protein (high levels indicating mutant, stabilised p53 protein) and by sequencing of the p53 gene. We found only a single Puma-deficient lymphoma (which also lacked Noxa) in which the p53 pathway was clearly inactive. Garrison et al. ${ }^{43}$ have now also reported that the p53 pathway is perturbed in some Puma-deficient lymphomas' in contrast to a prior study involving knockdown of puma. ${ }^{11}$ Hence, we conclude that the loss of Puma does not entirely supplant the need for loss of p53 function, but it does appear to substantially reduce the selective pressure. Retention of some selection for p53 loss is to be expected, because p53 can prevent tumour development through several non-apoptotic mechanisms, such as DNA repair and senescence. ${ }^{1}$

Concluding remarks. In the $\mathrm{E}_{\mu}-m y c$ lymphoma model, Puma appears to have a major tumour suppressor function, particularly in $\mathrm{slg}^{+} \mathrm{B}$ cells, where Bim seems to have a similar role. ${ }^{10}$ Although the role of Noxa seems more limited, the accelerated lymphomagenesis in both the pre-B and B-cell compartments produced by loss of Noxa on a puma heterozygous background demonstrates that it can contribute. The cell type-specific action of Noxa and Puma demonstrated here underlines the complexities of the apoptotic programme and the process of tumorigenesis and has important implications for the understanding and treatment of human cancer. As around half of all human tumours have lost p53 function, it will be important to learn how to restore this apoptotic pathway by identifying other ways to increase Puma or Noxa expression or to mimic their function, such as with $\mathrm{BH} 3$ mimetic agents. ${ }^{8}$

\section{Materials and Methods}

Mice. All experiments with mice conformed to the guidelines of the Melbourne Research Directorate Animal Ethics Committee. Generation and genotyping of mice deficient for Noxa, ${ }^{19}$ Puma $^{19}$ or both ${ }^{24}$ (all generated on an inbred C57BL/6 background) and those lacking $p 53^{44}$ (generated on a mixed C57BL/6x129SV background but backcrossed with C57BL/6 mice for $>20$ generations) have been described. $\mathrm{E} \mu$-myc mice (backcrossed onto a $\mathrm{C} 57 \mathrm{BL} / 6$ background for $>20$ generations), which overexpress c-Myc in B-lymphoid cells under control of the immunoglobulin heavy chain gene enhancer $(\mathrm{E} \mu)$, have been described. ${ }^{25,28}$ For this study, $\mathrm{E} \mu-\mathrm{myc}$ males were crossed with $p 53^{-1-}$ females to generate $\mathrm{E} \mu-\mathrm{myc} /$ $p 53^{+/-}$offspring and with puma ${ }^{-1-}$ and noxa ${ }^{-1-}$ females to produce $\mathrm{E} \mu-\mathrm{mycl}$ puma $^{+/-}$or $\mathrm{E} \mu-\mathrm{myc} / \mathrm{noxa}^{+1-}$ males, which were then crossed with puma ${ }^{-1-}$ or noxa ${ }^{-l-}$ females to yield $\mathrm{E} \mu-\mathrm{myc} / \mathrm{puma}^{-1-}$ or $\mathrm{E} \mu-\mathrm{myc} / \mathrm{noxa}{ }^{-l-}$ progeny, respectively. Similarly, $\mathrm{E} \mu-\mathrm{myc} / \mathrm{noxa}^{-1-}$ males were crossed with noxa ${ }^{-l}$ puma $^{-1-}$ double knockout (DKO) females to generate $\mathrm{E} \mu$-mycl noxa ${ }^{-1-}$ puma $^{+/-}$males, which were then bred to noxa ${ }^{-l-}$ puma $^{-1-}$ females to yield $\mathrm{E} \mu-\mathrm{myc} / \mathrm{noxa}^{-1-}$ puma $^{-1-}$ mice. E $\mu$-myc transgenic offspring were identified at 4 weeks of age from the increased size of their leukocyte nuclei using a Coulter particle count and size analyser Z2 (Beckman Coulter). ${ }^{28}$ Genotyping for p53 alleles was performed by PCR on genomic DNA using primers $5^{\prime}$ TTATGAGCCACCCGAGGT, $5^{\prime}$ TATACTCAGAGCCGGCCT and 5'TCCTCGTGCTTTACGGTATC. Mice used for mating were censored from the analysis as mated mice have a delayed tumour onset (EM Michalak, A Strasser unpublished observations).

Cell culture and cell viability assays. FACS-sorted pro-B, pre-B and $\mathrm{slg}^{+} \mathrm{B}$ cells were cultured at a starting density of $2-5 \times 10^{5} / \mathrm{ml}$ at $37^{\circ} \mathrm{C}$ in a humidified $10 \% \mathrm{CO}_{2}$ incubator in high-glucose Dulbecco's Modified Eagle's medium supplemented with $10 \%$ fetal calf serum (JRH Biosciences), $50 \mu \mathrm{M}$ 2-mercaptoethanol (Sigma) and $100 \mu \mathrm{M}$ asparagine (Sigma). Cell viability was measured by FACS analysis as the fraction of cells not stained by either Annexin V-FITC or PI as described. ${ }^{19}$ The extent of apoptosis induced specifically by etoposide was calculated using the following equation: [induced apoptosis (spontaneous apoptosis/100 - spontaneous apoptosis)].

Immunofluorescence staining, flow cytometric analysis and cell sorting. FACS analysis and cell sorting were performed using monoclonal antibodies as described ${ }^{19}$ and a FACScan (Becton Dickinson) for analysis. For survival assays, pro-B cells $\left(\mathrm{B}_{2} 2 \mathrm{O}^{+} \mathrm{CD} 3^{+} \mathrm{slgM}^{-} \mathrm{slgD}^{-}\right.$or $\mathrm{B}_{2} 2 \mathrm{O}^{+}$

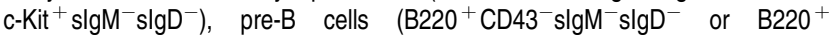

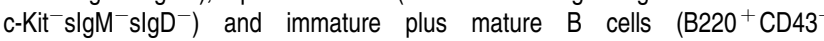
$\mathrm{slgM}^{+} \mathrm{slgD}^{+}$or $\mathrm{B}^{-220^{+} \mathrm{C}^{-K i t}}{ }^{-} \mathrm{slgM}^{+} \mathrm{slgD}^{+}$) were sorted from bone marrow or spleen using a MoFlo (Cytomation) or a Diva (Becton Dickinson) cell sorter.

Haematopoietic cell analysis. Spleen, lymph nodes (axillary, brachial, inguinal), bone marrow (both femora) and peripheral blood of healthy 4- to 6-weekold mice were analysed as described. ${ }^{24}$ To confirm that mice lacked transplantable tumour cells at the time of analysis, two C57BL/6 recipients per mouse analysed were injected with 2-6 $\times 10^{6}$ spleen cells and monitored for lymphoma-free survival for at least 50 days. Blood leukocytes for 4 -week old mice were enumerated using a Coulter particle count and size analyser Z2 (Beckman Coulter) and those from 5to 6-week-old pre-malignant mice and tumour-burdened mice using an ADVIA haematology system (Bayer).

Western blot analysis. Western blot analysis was performed by standard procedures using protein extracted from primary lymphomas, and the blots probed with the following antibodies: rabbit polyclonal anti-Puma (directed to the Puma N terminus; ProSci), CM5 rabbit polyclonal anti-mouse p53 (Novacastra), 3F11 hamster monoclonal anti-mouse Bcl-2 (Pharmingen), rabbit polyclonal anti-p19Arf (AbCam) and 5-C3-1 rat monoclonal anti-mouse p19Arf (kind gift of Dr. Roussel), rabbit polyclonal anti-Bim (Stressgen), 3C5 rat monoclonal anti-Bim (Alexis), 2H12 mouse monoclonal anti-Bcl-X (BD Pharmingen), rabbit polyclonal anti-Mcl-1 (Rockland). Antibodies to $\beta$-actin (AC-40, Sigma) or HSP70 (rat monoclonal antibody N6, a gift from Dr R Anderson, Peter MacCallum Cancer Centre, Melbourne) provided loading controls.

Real-time qRT-PCR analysis. Bone marrow B-lymphoid subsets were sorted as described above. RNA was prepared using the RNeasy Kit (Qiagen). First strand cDNA was prepared from 0.5-1.5 $\mu \mathrm{g}$ RNA using the Taqman RT system (Roche). Real-time PCR was performed using the ABI Prism 7900 (Applied 
Biosystems) and the QuantiTect SYBR Green PCR Kit (Qiagen) in $15 \mu$ reaction volumes. Data analyses were performed with the $\triangle \mathrm{CT}$ method using $\beta$-actin as an internal control. Primer sequences are provided in the Supplementary Materials.

Analysis of Ink4A/Arf locus and p53 mutation status in lymphomas. Vials of cryo-preserved lymphomas were thawed, dead cells removed using a Ficoll gradient and genomic DNA generated. Multiplex PCR analysis of genomic DNA for the Ink4A/Arf locus was performed to reveal gross deletions, using exon-specific primers for $\alpha$-actin, exons $2,1 \alpha$ and $1 \beta$ as described earlier. ${ }^{36,45}$ Sequencing of $p 53$ from genomic DNA was performed using two primer sets designed for each of exons 4-10 (the second set used if required for clarification). PCR products were purified and sequencing was performed using the BigDye Terminator cycle sequencing kit (Applied Biosystems). Primer sequences are available upon request.

Statistical analysis. Prism software (GraphPad Software Inc.) was used for generating Kaplan-Meier plots and for performing statistical analysis (using a log-rank test) of survival of mice and tumour onset. All other statistical analyses used two-tailed $t$-tests assuming equal variances. Cell counts and spleen weights were tested on the log-scale, whereas percentage data were tested on the arc sine scale. ${ }^{46}$ Trend test was performed by linear regression. $P$-values of less than 0.05 were considered to indicate statistical significance.

Acknowledgements. We thank Professor S Cory and Drs. A Villunger, DCS Huang, $\mathrm{H}$ Puthalakath, $\mathrm{P}$ Bouillet, $\mathrm{C}$ Vandenberg and $\mathrm{A}$ Egle for their input and interesting discussions; $K$ Vella, K Pioch, $N$ lannarella, $G$ Siciliano and $A$ Naughton for animal care; Dr. F Battye, C Tarlinton, V Milovac, J Garbe and C Young for cell sorting; T Nikolaou and G Thomas for $\gamma$-irradiation; J Corbin for automated blood analysis; B Helbert and C Young for genotyping; Dr. S Mihajlovic, A Hasanein, K Weston for histological sections; P Bouillet and the late A W Harris for mice. This work was supported by fellowships and grants from the NHMRC (Canberra; program no. 257502; RD Wright Biomedical CDA 406675); the Leukemia and Lymphoma Society (SCOR grant no. 7015); the NIH (CA043540-18 and CA80188-6); the JDRF/NHMRC; the Leukemia Research Foundation (LRF) (Post-graduate Scholarship to LH); and the Cancer Council Victoria (Postdoctoral Cancer Research Fellowship to EMM). EMM contributed to experimental design, performed experiments, analysed results, made the figures and wrote the paper; EJ, LH, MSC and LT contributed to some experiments; GKS aided the statistical analysis; CLS designed experiments, assisted with interpretation and contributed to writing the article; JMA assisted with interpretation and contributed to writing the article; AS conceived the study, designed the research, assisted with interpretation and contributed to writing the article.

Conflict of interest/disclosure: The authors declare no competing financial interests.

1. Vousden KH, Lu X. Live or let die: the cell's response to p53. Nat Rev Cancer 2002; 2 $594-604$.

2. Kastan MB. Wild-type p53: tumors can't stand it. Cell 2007; 128: 837-840.

3. Wang Y, Szekely L, Okan I, Klein G. Wiman KG. Wild-type p53-triggered apoptosis is inhibited by bcl-2 in a v-myc-induced T-cell lymphoma line. Oncogene 1993; 8: 3427-3431.

4. Strasser A, Harris AW, Cory S. BCl-2 transgene inhibits T cell death and perturbs thymic self-censorship. Cell 1991; 67: 889-899.

5. Strasser A, Harris AW, Jacks T, Cory S. DNA damage can induce apoptosis in proliferating lymphoid cells via p53-independent mechanisms inhibitable by Bcl-2. Cell 1994; 79: 329-339.

6. Youle RJ, Strasser A. The BCL-2 protein family: opposing activities that mediate cell death Nat rev 2008; 9: 47-59.

7. Danial NN, Korsmeyer SJ. Cell death: critical control points. Cell 2004; 116: 205-219.

8. Adams JM, Cory S. The Bcl-2 apoptotic switch in cancer development and therapy. Oncogene 2007; 26: 1324-1337.

9. Cory S, Adams JM. The Bcl2 family: regulators of the cellular life-or-death switch. Nat Rev Cancer 2002; 2: 647-656.

10. Egle A, Harris AW, Bouillet P, Cory S. Bim is a suppressor of Myc-induced mouse B cell leukemia. Proc Natl Acad Sci USA 2004; 101: 6164-6169.

11. Hemann MT, Zilfou JT, Zhao Z, Burgess DJ, Hannon GJ, Lowe SW. Suppression of tumorigenesis by the p53 target PUMA. Proc Natl Acad Sci USA 2004; 101: 9333-9338.

12. Sturm I, Stephan C, Gillissen B, Siebert R, Janz M, Radetzki S et al. Loss of the tissuespecific proapoptotic $\mathrm{BH}$-only protein Nbk/Bik is a unifying feature of renal cell carcinoma. Cell Death Differ 2006; 13: 619-627.
13. Tagawa H, Karnan S, Suzuki R, Matsuo K, Zhang X, Ota A et al. Genome-wide arraybased CGH for mantle cell lymphoma: identification of homozygous deletions of the proapoptotic gene BIM. Oncogene 2005; 24: 1348-1358.

14. Mestre-Escorihuela C, Rubio-Moscardo F, Richter JA, Siebert R, Climent J, Fresquet V et al. Homozygous deletions localize novel tumor suppressor genes in B-cell lymphomas. Blood 2007; 109: 271-280

15. Oda E, Ohki R, Murasawa H, Nemoto J, Shibue T, Yamashita T et al. Noxa, a BH3-only member of the bcl-2 family and candidate mediator of p53-induced apoptosis. Science (New York, NY) 2000; 288: 1053-1058.

16. Nakano K, Vousden KH. PUMA, a novel proapoptotic gene, is induced by p53. Mol Cell 2001; 7: 683-694.

17. Yu J, Zhang L, Hwang PM, Kinzler KW, Vogelstein B. PUMA induces the rapid apoptosis of colorectal cancer cells. Mol Cell 2001; 7: 673-682.

18. Han J, Flemington C, Houghton AB, Gu Z, Zambetti GP, Lutz RJ et al. Expression of bbc3, a pro-apoptotic $\mathrm{BH}$-only gene, is regulated by diverse cell death and survival signals. Proc Natl Acad Sci USA 2001; 98: 11318-11323.

19. Villunger A, Michalak EM, Coultas L, Müllauer F, Böck G, Ausserlechner MJ et al. p53- and drug-induced apoptotic responses mediated by BH3-only proteins Puma and Noxa. Science (New York, NY) 2003; 302: 1036-1038.

20. Jeffers JR, Parganas E, Lee $Y$, Yang C, Wang J, Brennan J et al. Puma is an essential mediator of p53-dependent and -independent apoptotic pathways. Cancer Cell 2003; 4: 321-328.

21. Erlacher M, Michalak EM, Kelly PN, Labi V, Niederegger H, Coultas L et al. BH3-only proteins Puma and Bim are rate-limiting for \{gamma\} -radiation and glucocorticoid-induced apoptosis of lymphoid cells in vivo. Blood 2005; 106: 4131-4138.

22. Shibue T, Takeda K, Oda E, Tanaka H, Murasawa H, Takaoka A et al. Integral role of Noxa in p53-mediated apoptotic response. Genes Dev 2003; 17: 2233-2238.

23. Naik E, Michalak EM, Villunger A, Adams JM, Strasser A. UV-radiation triggers apoptosis of fibroblasts and skin keratinocytes mainly via the BH3-only protein Noxa. J Cell Biol 2007; 176: 415-424.

24. Michalak EM, Villunger A, Adams JM, Strasser A. In several cell types the tumour suppressor $\mathrm{p} 53$ induces apoptosis largely via Puma but Noxa can contribute. Cell Death Differ 2008: 15: 1019-1029.

25. Adams JM, Harris AW, Pinkert CA, Corcoran LM, Alexander WS, Cory S et al. The c-myc oncogene driven by immunoglobulin enhancers induces lymphoid malignancy in transgenic mice. Nature 1985; 318: 533-538.

26. Langdon WY, Harris AW, Cory S, Adams JM. The c-myc oncogene perturbs B lymphocyte development in $\mathrm{E} \mu$-myc transgenic mice. Cell 1986; 47: 11-18.

27. Jacobsen KA, Prasad VS, Sidman CL, Osmond DG. Apoptosis and macrophage-mediated deletion of precursor $\mathrm{B}$ cells in the bone marrow of $\mathrm{E} \mu$-myc transgenic mice. Blood 1994; 84: 2784-2794

28. Harris AW, Pinkert CA, Crawford M, Langdon WY, Brinster RL, Adams JM. The E $\mu$-myc transgenic mouse: a model for high-incidence spontaneous lymphoma and leukemia of early B cells. J Exp Med 1988; 167: 353-371.

29. Evan Gl, Wyllie AH, Gilbert CS, Littlewood TD, Land H, Brooks $\mathrm{M}$ et al. Induction of apoptosis in fibroblasts by c-myc protein. Cell 1992; 69: 119-128.

30. Strasser A, Elefanty AG, Harris AW, Cory S. Progenitor tumours from Em-bcl-2-myc transgenic mice have lymphomyeloid differentiation potential and reveal developmental differences in cell survival. EMBO J 1996; 15: 3823-3834.

31. Zindy F, Eischen CM, Randle DH, Kamijo T, Cleveland JL, Sherr CJ et al. Myc signaling via the ARF tumor suppressor regulates p53-dependent apoptosis and immortalization. Genes Dev 1998; 12: 2424-2433.

32. Nilsson JA, Cleveland JL. Myc pathways provoking cell suicide and cancer. Oncogene 2003; 22: 9007-9021.

33. Eischen CM, Weber JD, Roussel MF, Sherr CJ, Cleveland JL. Disruption of the ARFMdm2-p53 tumor suppressor pathway in Myc-induced lymphomagenesis. Genes Dev 1999; 13: 2658-2669.

34. Eischen CM, Woo D, Roussel MF, Cleveland JL. Apoptosis triggered by myc-induced suppression of $\mathrm{Bcl}-\mathrm{X}_{\mathrm{L}}$ or $\mathrm{Bcl}-2$ Is bypassed during lymphomagenesis. Mol cell biol 2001; 21: 5063-5070.

35. Maclean KH, Keller UB, Rodriguez-Galindo C, Nilsson JA, Cleveland JL. C-Myc augments gamma irradiation-induced apoptosis by suppressing Bcl-XL. Mol cell biol 2003; 23: 7256-7270.

36. Schmitt CA, McCurrach ME, de Stanchina E, Wallace-Brodeur RR, Lowe SW. INK4a/ARF mutations accelerate lymphomagenesis and promote chemoresistance by disabling p53. Genes Dev 1999; 13: 2670-2677.

37. Sherr CJ. The INK4a/ARF network in tumour suppression. Nat Rev Mol Cell Biol 2001; 2: 731-737.

38. Bertwistle D, Zindy F, Sherr CJ, Roussel MF. Monoclonal antibodies to the mouse p19(Arf) tumor suppressor protein. Hybridoma and hybridomics 2004; 23: 293-300.

39. Juin P, Hueber A-O, Littlewood T, Evan G. c-Myc-induced sensitization to apoptosis is mediated through cytochrome $c$ release. Genes Dev 1999; 13: 1367-1381.

40. Kelly PN, Puthalakath H, Adams JM, Strasser A. Endogenous bcl-2 is not required for the development of E\{micro\}-myc-induced B-cell lymphoma. Blood 2007; 109: 4907-4913.

41. Chen L, Willis SN, Wei A, Smith BJ, Fletcher JI, Hinds MG et al. Differential targeting of prosurvival $\mathrm{Bcl}-2$ proteins by their $\mathrm{BH}$-only ligands allows complementary apoptotic function. Mol Cell 2005; 17: 393-403. 
42. Kuwana T, Bouchier-Hayes L, Chipuk JE, Bonzon C, Sullivan BA, Green DR et al. BH3 domains of $\mathrm{BH} 3$-only proteins differentially regulate bax-mediated mitochondrial membrane permeabilization both directly and indirectly. Mol Cell 2005; 17: 525-535.

43. Garrison SP, Jeffers JR, Yang C, Nilsson JA, Hall MA, Rehg JE et al. Selection against PUMA gene expression in Myc-driven B-cell lymphomagenesis. Mol cell biol 2008; 28: 5391-5402.
44. Jacks $T$, Remington $L$, Williams BO, Schmitt EM, Halachmi S, Bronson RT et al. Tumor spectrum analysis in p53-mutant mice. Curr Biol 1994; 4: 1-7.

45. Schmitt CA, Fridman JS, Yang M, Baranov E, Hoffman RM, Lowe SW. Dissecting p53 tumor suppressor functions in vivo. Cancer Cell 2002; 1: 289-298.

46. Zar JH. Biostatistical Analysis. New Jersey: Prentice Hall Int, 1999

Supplementary Information accompanies the paper on Cell Death and Differentiation website (http://www.nature.com/cdd) 